Archive for

Organic Chemistry

Arkivoc 2019, part ii, 65-85

\title{
From simple phenols to potent chain-breaking antioxidants by transposition of benzo[1,4]oxathiines to benzo[b]thiophenes
}

\author{
Caterina Viglianisi, ${ }^{\mathrm{a}}$ Leonardo Di Pietro, ${ }^{\mathrm{a}}$ Valentina Meoni, ${ }^{\mathrm{a}}$ Riccardo Amorati, ${ }^{\mathrm{b}}$ Stefano Menichetti ${ }^{\mathrm{a}}$ \\ ${ }^{a}$ Department of Chemistry "U. Schiff", University of Firenze, \\ Via della Lastruccia 3-13, 50019 Sesto Fiorentino, Italy \\ ${ }^{b}$ Department of Chemistry "G. Ciamician", University of Bologna, Via San Giacomo 11, 40126 Bologna, Italy \\ Email: caterina.viglianisi@unifi.it
}

Dedicated to Professor Lorenzo Testaferri in the occasion of his $75^{\text {th }}$ birthday

Received 08-01-2019

Accepted 08-29-2019

Published on line $09-24-2019$

\section{Abstract}

Simple phenols, including food stock recycled derivatives, were used for the synthesis of 1,4-benzooxathiine intermediates, with limited or no antioxidant activity. Depending upon their substitution pattern, these compounds, through an acid promoted transposition, can be converted into o-hydroxydihydrobenzo $[b]$ thiophenes or o-hydroxy-benzo $[b]$ thiophenes as a new class of potent chain-breaking antioxidants, showing, in the reaction with alkyl peroxyl radicals, kinetic rate constants $\left(k_{\text {inh }}\right)$ comparable to that of $\alpha$-tocopherol, the more potent natural lipophilic phenolic antioxidant.

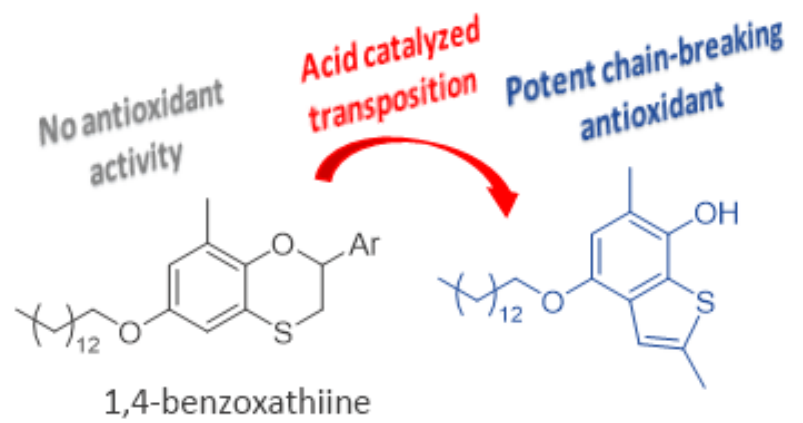

benzo[b]thiophene

$\mathrm{K}_{\text {inh }} 6.29 \times 10^{6} \mathrm{M}^{-1} \mathrm{~s}^{-1}$

Keywords: Antioxidant, transposition, sulfur heterocycle, benzo[b]thiophenes, phenols 


\section{Introduction}

Reactive Oxygen Species (ROS) and other free radicals are natural by-products of the human metabolism playing an important role in cell signalling, homeostasis and biochemical transformations. ${ }^{1-3}$ On the other hand, they can also be formed through a variety of exogenous events such as exposure to UV light and ionizing radiation, smoking, air pollution and inflammation. Indeed, an anomalous high concentration of ROS in tissues is strictly related to oxidative stress, in turn cause and effect of several diseases and aging itself. ${ }^{4-11}$

Our endogenous antioxidant defense systems have the function to control ROS level in order to conserve their biological benefits avoiding risky high concentrations and preventing oxidative stress and related diseases such as neurodegeneration, cardiovascular injury, mutation of healthy cells into cancerous ones, etcetera. ${ }^{4-11}$

On the other hand, many substances, taken with diet, are able to control oxidative processes acting as exogenous antioxidants. In particular, natural and synthetic phenols have the ability to prevent auto-oxidation acting as chain breaking antioxidant a process that is crucial for the protection of cell membranes and LDL.

Phenols ( $\mathrm{ArOH})$ are known to reduce the rates of oxidation of organic materials by transferring an $\mathrm{H}$ atom $\left(\mathrm{H}^{\circ}\right)$ from their $\mathrm{OH}$ groups to the more common chain-carrying species i.e. peroxyl radicals (ROO*). ${ }^{12-14}$ Polyphenols as flavonoids ${ }^{15-17}$ (vitamin P) and tocopherols ${ }^{18,19}$ (vitamin E) are the more important examples of such natural antioxidants.

Recently, we focused our attention on some sulfur containing phenols, namely, o-hydroxydihydrobenzo[ $b]$ thiophenes ${ }^{20}$ and benzo[ $\left.b\right]$ thiophenes ${ }^{21}$ as efficient multi-defense antioxidants.

In particular, we have settled out new acid-catalysed transpositions that allow, in few steps with reasonably good overall yields, to transform easily accessible benzo[1,4]oxathiines ${ }^{20-28}$ into 7-hydroxydihydrobenzo[b]thiophenes or 7-hydroxy-benzo[b]thiophenes (Figure 1). These benzofused phenolic systems showed antioxidant activities similar to that of $\alpha$-tocopherol ( $\alpha-\mathrm{TOH})$, the main component of vitamin $\mathrm{E}$ and the more potent lipophilic antioxidant know in nature, showing in the reaction with ROO ${ }^{\bullet}$ kinetic constants $\left(\mathrm{k}_{\text {inh }}\right)$ as high as $3.2 \times 10^{6} \mathrm{M}^{-1} \mathrm{~s}^{-1}$.<smiles>COc1cc(C)c(O)c2c1C([Al])CS2</smiles>

dihydrobenzo[ $b]$ thiophene $\mathrm{k}_{\text {inh }} 1.5 \times 10^{6} \mathrm{M}^{-1} \mathrm{~s}^{-1}$

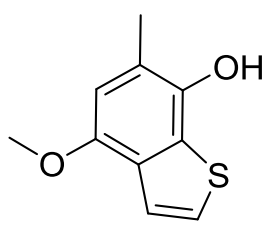

benzo $[b]$ thiophene $\mathrm{k}_{\text {inh }} 5.0 \times 10^{6} \mathrm{M}^{-1} \mathrm{~s}^{-1}$

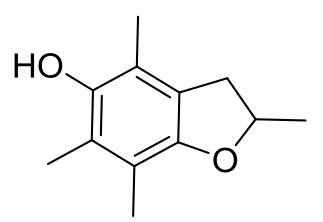

dihydrobenzo[b]furane

$\mathrm{k}_{\text {inh }} 5.4 \times 10^{6} \mathrm{M}^{-1} \mathrm{~s}^{-1}$

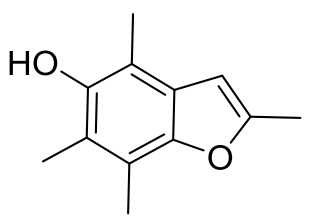

benzo[b]furane

$\mathrm{k}_{\text {inh }} 0.5 \times 10^{6} \mathrm{M}^{-1} \mathrm{~s}^{-1}$

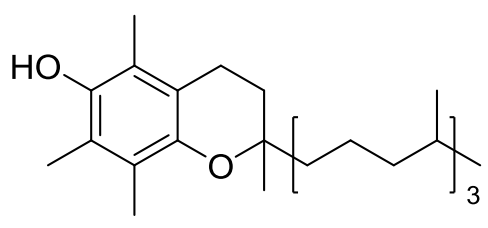

$\alpha$-Tocopherol ( $\alpha$-TOH)

$$
\mathrm{k}_{\text {inh }} 3.2 \times 10^{6} \mathrm{M}^{-1} \mathrm{~s}^{-1}
$$

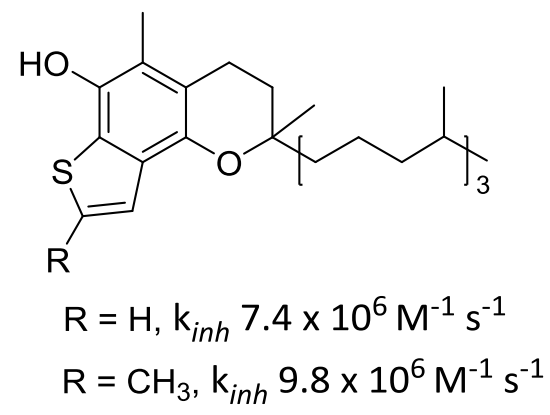

Figure 1. Structure and kinetic constants $\left(k_{i n h}\right)$ of model phenolic compounds discussed in this study. 
Moving from a 6 -hydroxychromane (like in $\alpha-\mathrm{TOH}$ ) to a 5 -hydroxydihydrobenzo[b]furane the $\mathrm{k}_{\text {inh }}$ slightly increases since the five-membered ring is almost coplanar with the aromatic ring, hence one of the lone pairs of the endocyclic $\mathrm{O}$ atom lays parallel to the aromatic $\pi$ orbitals allowing an optimal stabilization of the phenoxyl radical $\left(\mathrm{ArO}^{\circ}\right) .{ }^{29}$ On the other hand 5-hydroxybenzo[b]furane, despite its complete planarity, showed a ten time reduced hydrogen transfer ability due to the aromatization that, involving the lone pair of endocyclic $\mathrm{O}$ atom, reduces its electron donating ability and $\mathrm{ArO}^{\circ}$ stability. ${ }^{29}$ We demonstrated that, considering the corresponding sulfur heterocycles, moving from 7-hydoxydihydrobenzo[b]thiophenes to 7hydoxybenzo[b]thiophenes there is an overall increasing (up to three times) of the $\mathrm{k}_{\text {inh. }}{ }^{21}$ The (weak) intramolecular $\mathrm{H}$-bond stabilization of the $\mathrm{ArOH}$, and the electron donating effect stabilization of sulfur moieties on $\mathrm{ArO}^{\circ}$ do not allow to rationalize this unexpected result of $\mathrm{k}_{\text {inh }}$ increasing with aromatization. We have suggested that the extra stabilization of the phenoxyl radical in the benzothiophene compound is due to the contribution of a chalcogen-bond effect, ${ }^{30-35}$ namely the interaction between the high electron density around the oxygen centered radical of $\mathrm{ArO}^{\circ}$ and the sulfur $\sigma$-hole of the thiophene that ensures an overall increasing of the $\mathrm{H}^{\bullet}$ transfer attitude.

We applied this observation preparing a couple of super vitamin-E like phenolic antioxidants bearing a benzo[b]thiophene residue (Figure 1) perfectly suitable for studying the role of chain breaking activity in biological environments. ${ }^{21}$

In this paper, we report the scope and limitation of the transformation of different phenols (1), with limited antioxidant activity, through benzo[b]oxathiines 4 (typically without any pendant $\mathrm{OH}$, hence without any antioxidant activity), into o-hydroxy benzothiophene systems 5, 6 showing a remarkable chain breaking antioxidant ability (Scheme 1).

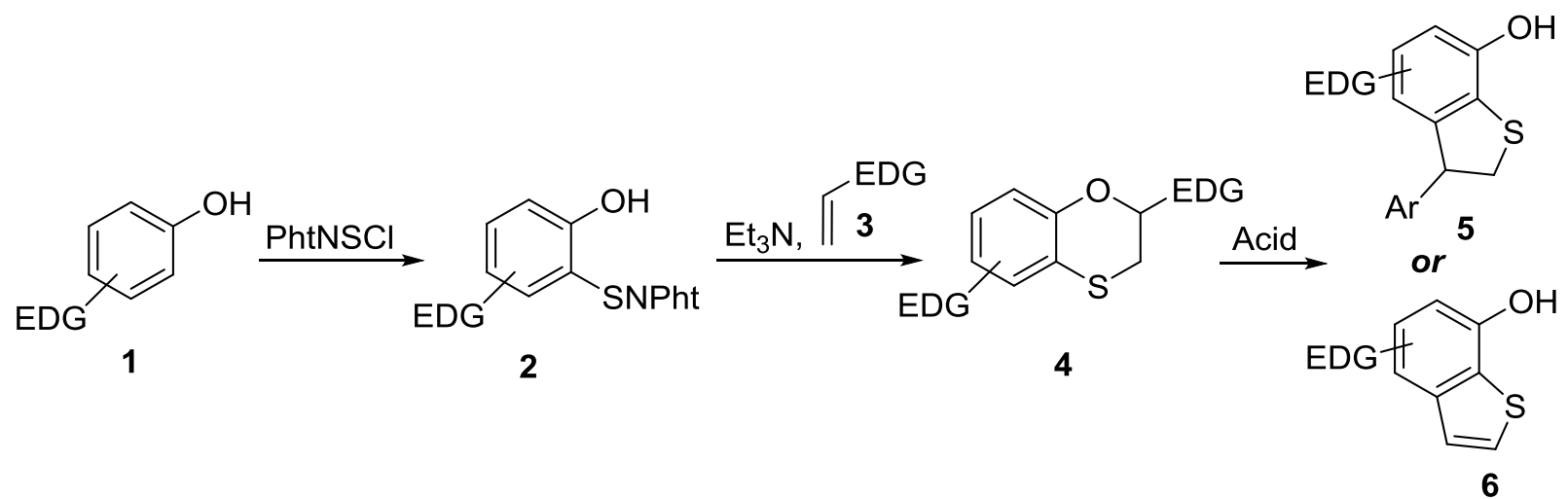

Scheme 1. The synthetic transformations considered in this study.

\section{Results and Discussion}

\section{Synthesis of $\boldsymbol{N}$-thiophthalimide derivatives $\mathbf{2}$}

Our research group has developed the synthesis of benzo[1,4]oxathiine derivatives that exploits the reactivity of ortho-hydroxy- $N$-thiophthalimides 2 in turn obtained by reaction of phthalimidesulfenyl chloride (PhtNSCl, $\mathrm{Pht}=$ Phthaloyl) with phenols containing at least one additional electron donor group (EDG). ${ }^{22-28} \mathrm{o}-\mathrm{Hydroxy}-\mathrm{N}-$ thiophthalimides 2 are the result of an electrophilic aromatic substitution $\left(S_{E} A r\right)$ that occurs without any catalyst under mild conditions. The sulfenylation with PhtNSCl proved to be highly ortho-hydroxy- 
regioselective and, typically, affords a mono-sulfenylated derivative. In fact, after the first substitution, the thiophthalimide group deactivates the aromatic ring toward further $\mathrm{S}_{\mathrm{E}} A$. Phenols $\mathbf{1 a - g}$ used as substrates and $\mathrm{N}$-thiophthalimides 2a-g prepared are depicted in table 1. Phenol 1a was synthesized through a Wolff-Kishner reduction starting from 2-hydroxy-5-methoxybenzaldehyde as previously reported. ${ }^{20}$ Derivative $\mathbf{1 b}$ is commercially available and tyrosol $\mathbf{1 c}$ is a natural phenolic antioxidant present in a variety of natural sources. Saturated cardanol $\mathbf{1 d}$ is obtained from anacardic acid, the main component of cashew nutshell liquid (CNSL), a by-product of cashew nut processing. Derivatives $\mathbf{1 e}$ and $\mathbf{1 f}$ were prepared by alkylation of commercially available 2-methyl- and 2-tert-butyl-hydroquinone (see experimental). The bromide used for alkylation was chosen to obtain derivatives $\mathbf{1 e}$ and $\mathbf{1 f}$ bearing a long saturated tail like in Tocopherols.

The dihydrobenzofuranol $\mathbf{1 g}$ was prepared in one-step starting from 2-t-butyl-5-methyl hydroquinone, 2methyl-2-propen-1-ol and $p$-toluensulfonic acid (PTSA). The steric hindrance of tert-butyl group allowed the complete control of the regiochemistry giving $\mathbf{1 g}$ as the unique phenol isolated in $74 \%$ (see experimental).

The synthesis of $\mathbf{N}$-thiophthalimide derivatives 2 (Table 1 ), was carried out following our standard procedure. To a $0.1 \mathrm{M}$ solution of each phenol in chloroform a $0.1 \mathrm{M}$ solution of phthalimidesulfenyl chloride in chloroform was added dropwise keeping the reaction mixture at $0^{\circ} \mathrm{C}$. Then the mixture was kept under stirring at room temperature until complete consumption of the starting phenol. The expected o-hydroxy- $N$ thiophthalimide derivatives $\mathbf{2 a - g}$ were obtained after a trivial aqueous work-up and solvent evaporation and typically used without further purification (Table 1).

Table 1. Synthesis of $N$-thiophthalimide derivatives 2

\begin{tabular}{|c|c|c|c|c|c|c|c|}
\hline Entry & 1 & 2 & 3 & 4 & 5 & 6 & 7 \\
\hline Phenol & $1 a$ & $1 b$ & $1 c$ & $1 d$ & $M_{12}$ & 120 & $1 \mathrm{~g}$ \\
\hline $\begin{array}{c}\text { Product } \\
\text { (yield) }\end{array}$ & $2 a$ & 2b (63\%) & $2 c(16 \%)$ & $2 d(\geq 99 \%)$ & $\mathbf{2 e}(\geq 99 \%)$ & $\mathbf{2 f}(\geq 99 \%)$ & $2 \mathrm{~g}(\geq 99 \%)$ \\
\hline
\end{tabular}

\section{Synthesis of benzo[1,4]oxathiine cycloadducts 4}

In the last three decades ${ }^{20-28}$ we demonstrated that the reaction of $o$-hydroxy- $N$-thiophthalimide derivatives 2a-g with a base, such as triethylamine, allows the formation of the corresponding 0 -thioquinones as the result of $\mathrm{ArOH}$ deprotonation and 1-4 elimination at sulfur of the phthalimide anion from the phenate ion (scheme 2). o-Thioquinones are transient intermediates, very efficient as electron-poor dienes in inverse electron demand hetero Diels-Alder reactions with a plethora of electron-rich alkenes (3, Figure 2 ) acting as dienophiles to afford of benzo[1,4]oxathiine cycloadducts 4 under mild conditions (Scheme 2). 


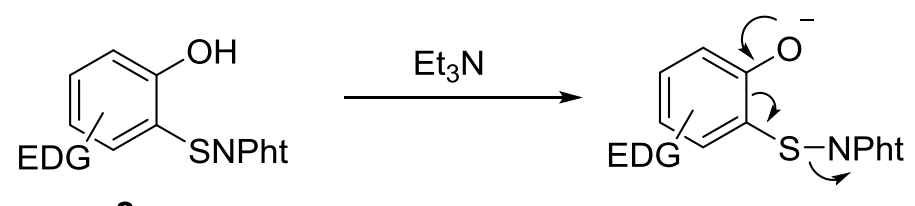

2
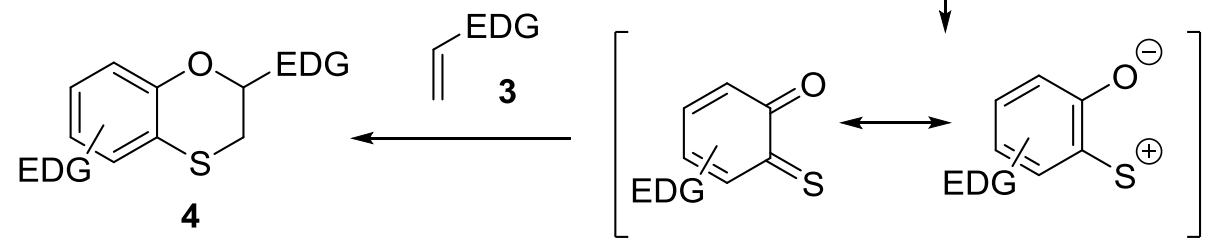

Scheme 2. Access to benzo[1,4]oxathiines 4 from o-hydroxy- $N$-thiophthalimides 2 via $o$-thioquinones.

Noteworthy, the high polarization of the hetero-diene ${ }^{36,37}$ ensures, in all cases, the formation of a single regioisomeric cycloadduct in which the oxygen atom of the thioquinone is bounded to the more electron-poor carbon atom of the dienophile (Scheme 2). Electron-rich dienophiles $\mathbf{3}$ used for this study are depicted in Figure 2. All dienophiles used are commercially available, apart from 4-methoxy- $\alpha$-methylstyrene (3c), which was prepared through a Wittig olefination from 4-methoxy-acetophenone and methyltriphenylphosphonium bromide as previously reported. ${ }^{20}$

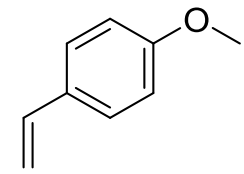

$3 a$

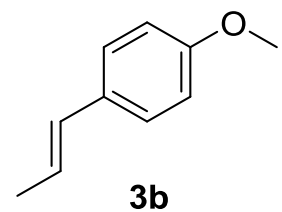

$3 \mathbf{b}$

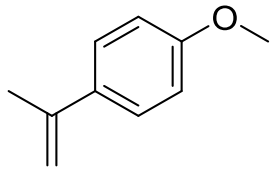

$3 c$

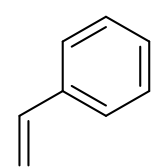

$3 d$

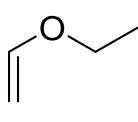

$3 e$<smiles>C/C=C/OCC</smiles>

$3 f$

Figure 2. Electron-rich alkenes used as dienophiles in this study.

The cycloaddition reactions were carried out as following: to a (roughly) $0.1 \mathrm{M}$ solution of the $o$-hydroxyl$\mathrm{N}$-thiophthalimide derivative $\mathbf{2}$ in chloroform, an excess (2-5 equiv) of the dienophile $\mathbf{3}$ was added followed by freshly distilled triethylamine (1 equiv). The mixture was kept under magnetic stirring at $60{ }^{\circ} \mathrm{C}$ until complete consumption of starting $o$-hydroxy- $N$-thiophthalimide. The crude obtained after an aqueous work-up was purified by column chromatography on silica gel to afford the desired benzo[1,4]oxathiine 4 as depicted in Table 2.

The use of an excess of dienophile was decided to speed up the cycloaddition allowing a relative fast consumption of the $o$-thioquinone. The reaction with styrene $3 \mathbf{d}$ was carried out in dichloroethane at $80{ }^{\circ} \mathrm{C}$ since the lack of EDG decreases its ability as dienophile.

The cycloaddition reactions were indeed completely regiocontrolled allowing the isolation of a single regioisomeric cycloadduct where the oxygen atom of the thioquinones binds to the more electron-poor carbon atom of the dienophile. Additionally, the cycloaddition occurs with retention of the alkene geometry, as expected for a concerted [4+2] process. Thus, reacting alkene 3f, commercially available as a 72:28 trans:cis mixture, allowed the isolation of cycloadduct $\mathbf{4 d f}$ as 72:28 trans:cis mixture of diastereoisomers (Table 2, entry 7), while reactions carried out with trans-anethole $\mathbf{3 b}$ gave trans-benzo[ $b][1,4]$ oxathiines $\mathbf{4 e b}$ and $\mathbf{4 f b}$ as single diastereoisomers (Table 2, entries 9, 11). 
Table 2. Synthesis of benzo[1,4]oxathiine cycloadducts 4

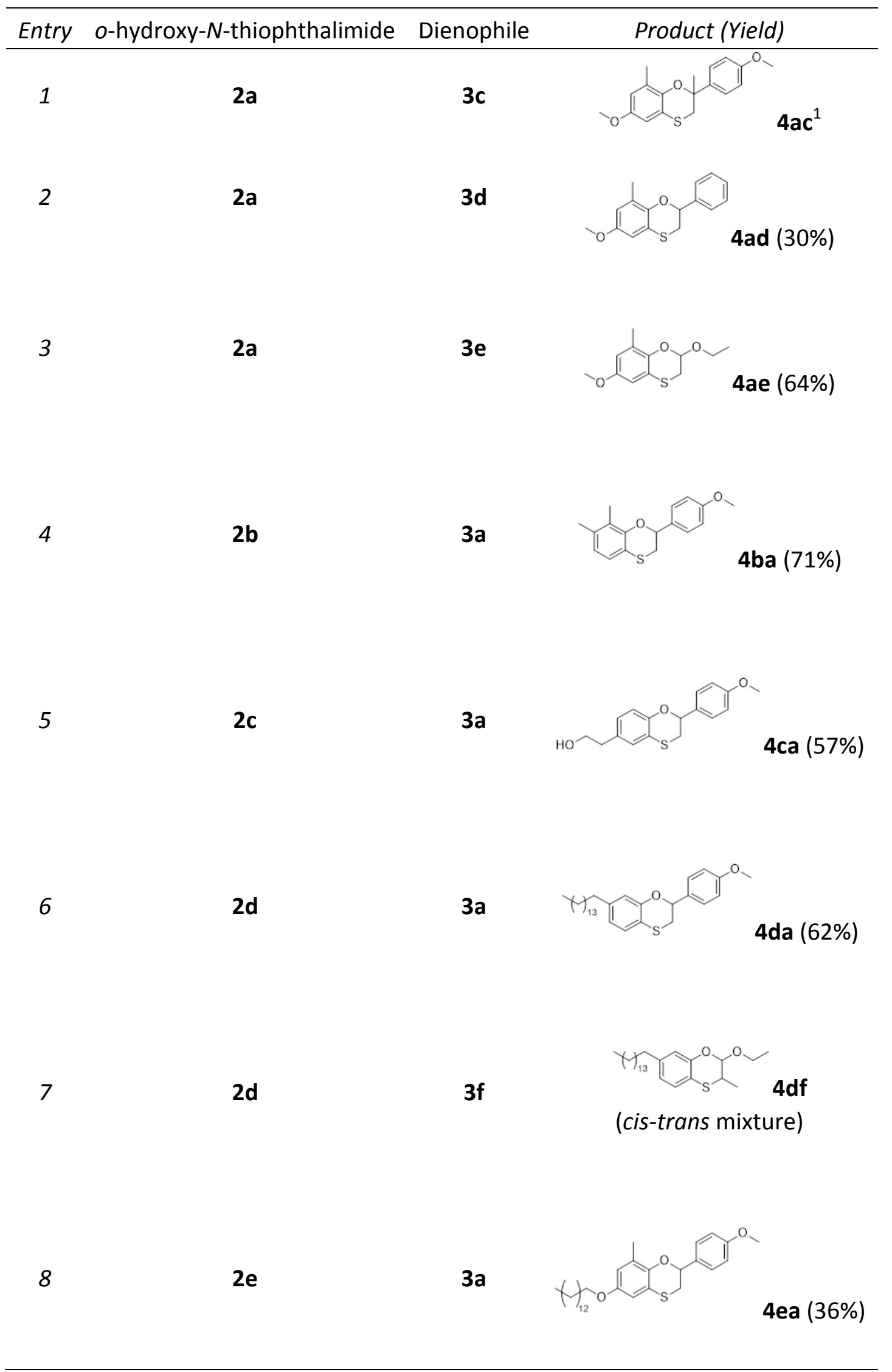


9

$2 e$

$3 b$

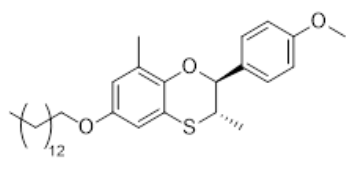

4eb (37\%)

$3 e$

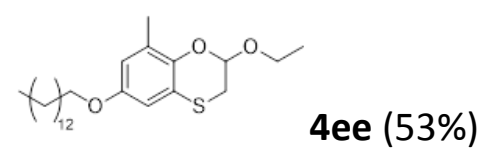

$3 b$

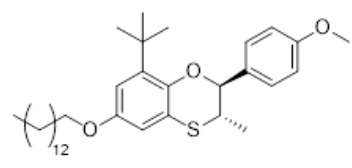

4fb (33\%)

$3 a$

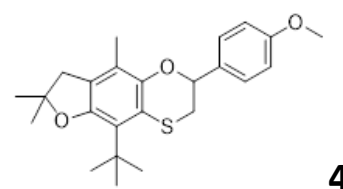

4ga (59\%) 


\section{Acid mediated transposition of benzo[1,4]oxathiines 4 to dihydrobenzo[b]thiophenes 5 and benzo[b]thiophenes 6}

Having in hand a variety of different substituted benzoxathiine cycloadducts 4 (Table 2) we had the opportunity to study and rationalize the limitation and scope of their transformation into 7-hydroxydihydrobenzo[b]thiophenes $5,^{20}$ and/or 7-hydroxybenzo[b]thiophenes $6{ }^{21}$ using the better condition for both processes, i.e. chloroform as solvent and $\mathrm{BF}_{3} . \mathrm{OEt}_{2}$ or triflic acid $(\mathrm{TfOH})$ as acid promoters. The mechanism we propose is depicted in Scheme 3 using derivative 4 ac as model substrate.

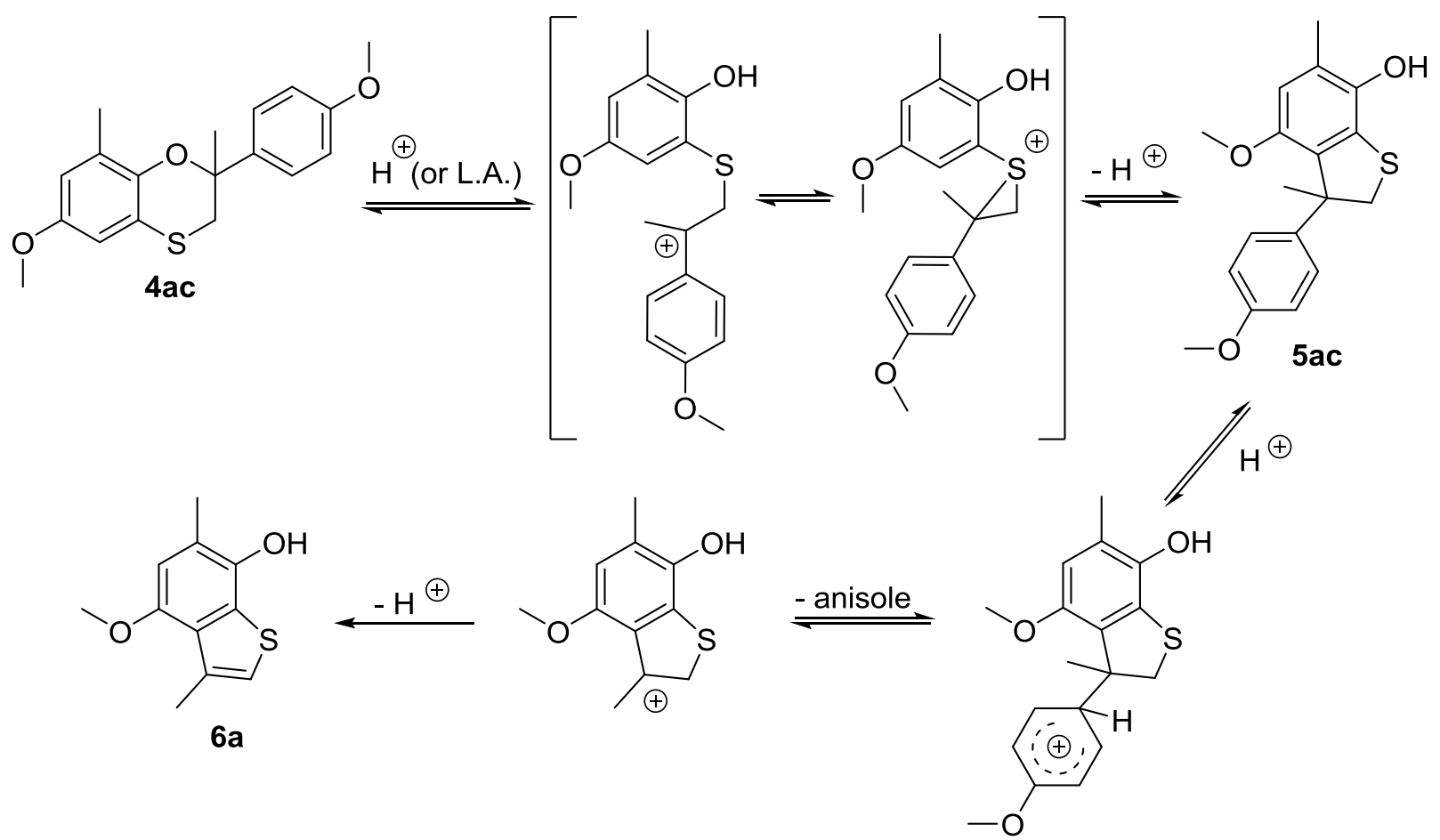

Scheme 3. Acid promoted transformation of benzoxathiines $\mathbf{4}$ into dihydrobenzo[ $b]$ thiophene $\mathbf{5}$ and benzo[b]thiophenes 6 .

Thus, benzoxathiine 4ac, under acid conditions gives ring opening of the benzo-fused heterocyclic ring with formation of a benzylic carbocation which, through an internal electrophilic alkylation ( $\left.i-S_{E} A r\right)$ gives rise to ring closure and formation of dihydrobenzo[b]thiophene 5ac. This first part of the process is directly related with the well-known chromane-indene acid catalysed transposition despite occurring under milder conditions. $^{38-44}$ In fact, using benzoxathiine as starting materials, the intermediate carbocation is stabilized by the anchimeric assistance of the sulfur atom and formation of a thiiranium ion. ${ }^{20}$ Once derivative 5 ac is formed and under harsh acid conditions, we postulated the possibility of a retro-alkylation $\left(r-S_{E} A r\right)$, via protonation of aromatic ring and elimination, in the case of 5ac, of anisole. The new cyclic carbocation formed easily deprotonate to give the aromatic benzo[b]thiophene $6 a^{21}$ (Scheme 3).

Keeping this mechanism in mind, we studied the behaviour of derivatives 4 as reported in Table 3 . Benzoxathiine $4 \mathrm{ac}$ reacts smoothly with $\mathrm{BF}_{3} \mathrm{Et}_{2} \mathrm{O}$ (3.0 equiv) giving $5 \mathrm{ac}$ in $66 \%$ yield. Indeed, the benzylic carbocation formed from 4ac is stabilized by the 4'-methoxy group on the aryl ring and by the methyl group on the benzylic carbon. Actually, the formation of high stabilized tertiary carbocation plays a crucial role in both processes since $4 \mathrm{ac}$ is the only derivative that allowed the isolation of the corresponding benzo[b]thiophene 6a (16\%) just under $\mathrm{BF}_{3} \cdot \mathrm{Et}_{2} \mathrm{O}$ catalysis (Table 3, entry 1 ). As a matter of fact, reacting 4ac with 1 equiv. of TfOH, 
6a becomes the only product observed in the crude mixture, and isolated in $46 \%$ yield (Table 3, entry 2), indicating an easy and fast transformation of 5 ac into 6a facilitated by the stability of the cyclic tertiary carbocation formed after anisole elimination (Scheme 3). The critical role of carbocation stability in both processes $\left(i-S_{E} A r\right.$ and $\left.r-S_{E} A r\right)$ depicted in Scheme 3 is boosted by the result obtained with derivative 4ab. In fact, in the absence of a 4'-metoxy group and alkyl substituents on benzylic carbon, the reaction does not take place with 3 equiv of $\mathrm{BF}_{3}{ }^{\circ} \mathrm{Et}_{2} \mathrm{O}$ at $60^{\circ} \mathrm{C}$ being the starting material stable under these conditions for more than $12 \mathrm{~h}$. Repeating the reaction under drastic acid conditions, 5 equiv of $\mathrm{TfOH}$ at $60{ }^{\circ} \mathrm{C}$, for $6.5 \mathrm{~h}$, we were able to isolate dihydrobenzo[b]thiophene 5 ad albeit in low yield, $25 \%$, while analysis of the crude pointed out a large amount of unreacted starting material without any trace of the corresponding benzo[ $b]$ thiophene.

Together with the role of carbocation stability, the substitution pattern on the oxathiine benzofused aryl

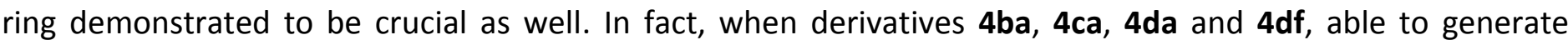
stabilized carbocations, were reacted with either $\mathrm{BF}_{3}{ }^{\cdot} \mathrm{Et}_{2} \mathrm{O}$ or $\mathrm{TfOH}$ at $60{ }^{\circ} \mathrm{C}$ any benzothiophene was observed yet, typically, an extensive decomposition of the starting materials was experienced (Table 3, entries 4-7). In all these compounds the position in the aromatic ring ortho to the sulfur atom is less nucleophilic due to the lack of the alkoxy group in ortho' position, a structural feature that demonstrated to be mandatory for the success of the procedure. This prevented the possibility to transform stock recycled phenols, like tirosol and cardanol, into potent chain breaking antioxidants. In perfect agreement with previous observations, benzoxathiines $4 \mathbf{e a}$ and $\mathbf{4 e b}$ easily reacted with $\mathrm{BF}_{3} \cdot \mathrm{Et}_{2} \mathrm{O}$ to give dihydrothiophenes $\mathbf{5 e a}$ and $\mathbf{5 e b}$ in $53 \%$ and $63 \%$ yield respectively (Table 3 , entries 8 and 9). For these derivatives the one-pot formation of benzothiophenes 6 from 4 was poor effective. However, benzo[b]thiophenes $\mathbf{6 b}$ and $\mathbf{6 c}$ were obtained in $48 \%$ and $50 \%$ yield respectively carrying out the process in two steps by reacting the corresponding dihydrobenzo[b]thiophenes 5 ea and 5 eb with 0.5 equiv of TfOH (Table 3, entries 10 and 11).

As a matter of fact, benzo[b]thiophene $\mathbf{6 b}$ was also prepared reacting benzoxathiine 4ee with 0.5 equiv. of $\mathrm{TfOH}$. In this case, the transposition was very fast and, in just a hour, thiophene $\mathbf{6 b}$ was the unique product of the reaction, while no trace of residual starting material or intermediate dihydrobenzo[b]thiophene were detected by TLC and ${ }^{1} \mathrm{H}$ NMR analysis of the crude mixture (Table 3, entry 12). Derivative 4ee was obtained using ethyl vinyl ether as dienophile (see Table 2 entry 10). Taking in consideration the mechanism depicted in Scheme 3 we can suggest that the first carbocation, obtained by oxathiine ring opening, is stabilized by the adjacent ethoxy group, while the aromatization process of the corresponding 3-ethoxydihydrobenzo[b]thiophene foresees and easy elimination of ethanol (see scheme 3). In other words, once the structural features required for both processes are maintained, the transformation occurs independently upon the presence of a $p$-methoxyaryl group on $\mathrm{C} 2$ of benzoxathiine.

As a further demonstration that a fine tuning of the substitution pattern is mandatory to achieve either dihydro- and benzo[b]thiophenes, compound $\mathbf{4} \mathbf{f b}$ was simply transformed into dihydrobenzo[b]thiophene $\mathbf{5} \mathbf{f b}$ in $45 \%$ yield using $\mathrm{BF}_{3} . \mathrm{Et}_{2} \mathrm{O}$ (Table 3, entry 13), however, all the attempts to push the reaction to the corresponding benzo[b]thiophenes using $\mathrm{TfOH}$ as promoter, from $\mathbf{4} \mathbf{f b}$ or $\mathbf{5} \mathbf{f b}$ as starting materials, failed while we observed extensive de-terbutylation and decomposition.

Eventually, we tested derivative 4ga, a benzo[1,4]oxathiine with a dihydrobenzofuranic moiety and no free nucleophilic positions on the benzofused aromatic ring (see Table 2 entry 14). Indeed, we used similar compounds for the preparation of the benzo[b]thiophenes containing the $\alpha$-TOH skeleton ${ }^{21}$ (Figure 1 ) exploiting a $\mathrm{TfOH}$ promoted de-terbutylation since to liberate the required nucleophilic position ortho to the sulfur atom. However, in this case the dimethyl-dihydrobenzofuranic ring proved to be poor stable under acid condition and de-terbutylation occurred together with rings opening preventing the thiophene ring formation (Table 3, entry 14). 
Table 3. Access to dihydrobenzo[ $b]$ thiophenes $\mathbf{5}$ and benzo $[b]$ thiophenes 6

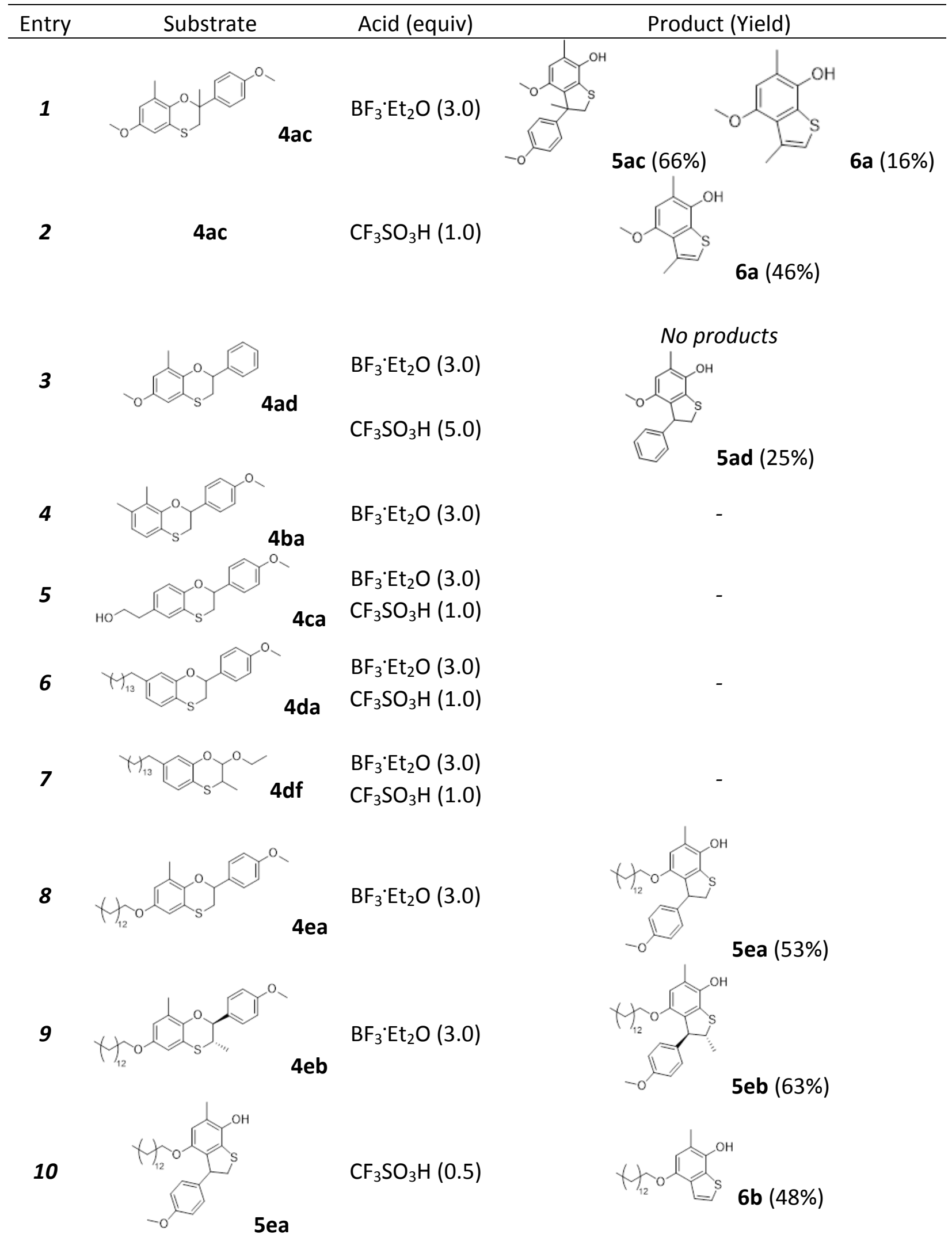




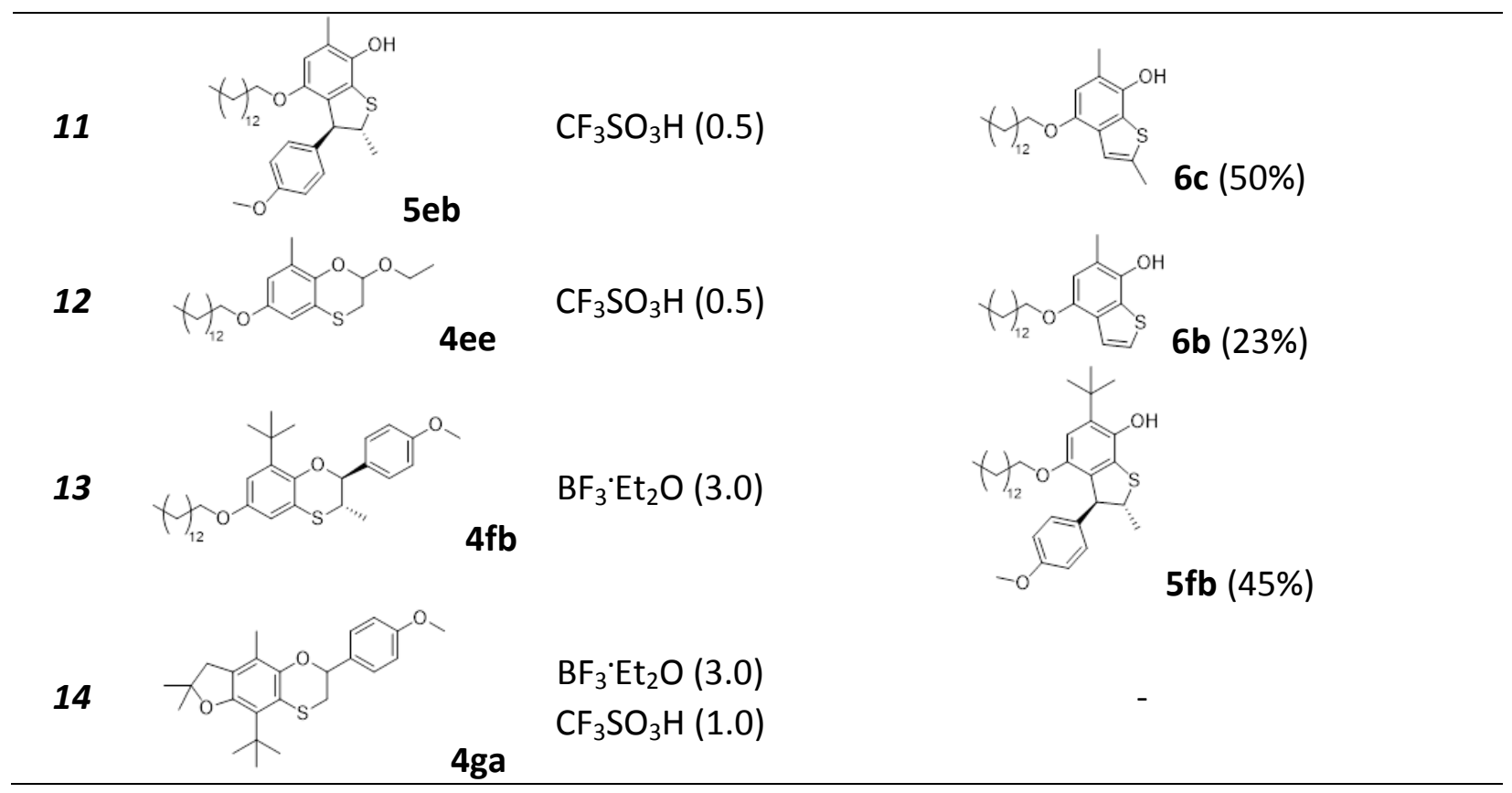

Chain-breaking antioxidant activity of dihydrobenzo[b]thiophenes 5 and benzo[b]thiophenes 6 The antioxidant activity of the dihydrobenzo[b]thiophenes 5 and benzo[b]thiophenes 6 was assessed by studying the inhibition of the thermally initiated autoxidation of styrene ( $\mathrm{R}=$ styrene, $50 \% \mathrm{v} / \mathrm{v}$ in chlorobenzene), used as reference hydrocarbon, under controlled conditions. Autoxidation of styrene is a radical chain reaction (see Equations 1-6) carried on mainly by alkylperoxyl radicals (ROO') which are representative of the reactive oxygen species responsible for the oxidation of natural lipids and man-made materials under air. The initiator is represented by azobis(isobutyronitrile) (AIBN), whose decomposition at $30^{\circ} \mathrm{C}$ originates a constant flux of free radicals (initiation rate, $\mathrm{Ri}$ ). The reaction was followed by measuring the oxygen consumption by an automatic oxygen uptake recording apparatus, build in our laboratory, based on a differential pressure transducer. $^{45-48}$

$$
\begin{aligned}
& \text { initiator } \stackrel{R_{i}}{\longrightarrow} \\
& \mathrm{R}^{\bullet}+\mathrm{O}_{2} \longrightarrow \mathrm{ROO}^{\bullet} \\
& \mathrm{ROO}+\mathrm{RH} \stackrel{k_{p}}{\longrightarrow} \mathrm{ROOH}+\mathrm{R}^{\bullet} \\
& \mathrm{ROO}^{\bullet}+\mathrm{ROO} \stackrel{2 k_{t}}{\longrightarrow} \text { non-radical products } \\
& \mathrm{ROO}^{\bullet}+\mathrm{ArOH} \stackrel{k_{\text {inh }}}{\longrightarrow} \mathrm{ROOH}+\text { ArO } \\
& \mathrm{ROO}^{\bullet}+\mathrm{ArO} \cdot \mathrm{non-radical} \mathrm{products} \\
& R_{i}=n[\text { ArOH }] / \tau \\
& \Delta \mathrm{O}_{2}=\left(k_{p} k_{\text {inh }}\right)[\text { styrene }] \ln (1-\mathrm{t} / \tau)
\end{aligned}
$$

In the absence of antioxidants, the $\mathrm{O}_{2}$ consumption is fast and linear, whereas in the presence of an antioxidant, the $\mathrm{O}_{2}$ consumption is retarded or completely inhibited for a period that depends on its 
concentration. The number of radicals trapped by each antioxidant molecule $(n)$ is related to the length of the inhibited period $\tau$ through Equation (7), in which the initiation rate Ri can be determined by using a reference antioxidant. The rate constant of the reaction of the antioxidant with ROO' radicals ( $k_{\text {inh }}$, see Equation 5$)$ was calculated by using Equation (8): A plot of $\Delta\left[\mathrm{O}_{2}\right] \mathrm{t}$ vs $\ln (1-\mathrm{t} / \tau)$ gives a straight line of slope $\mathrm{kp}$ [styrene]/kinh from which $k_{i n h}$ is obtained by using the known kp value at $30^{\circ} \mathrm{C}$ of styrene, that is, $41 \mathrm{M}^{-1} \mathrm{~s}^{-1}$. 48,49 The results obtained by using this method are reported in Table 4 and compared with that of $\alpha-\mathrm{TOH}$.

Table 4. $K_{\text {inh }}$ and $n$ values of derivatives 5 and 6 compared with those of $\alpha$-tocopherol

Entry $\quad k_{\text {inh } M^{-1} \mathrm{~s}^{-1}}$

From Table 4 we observe that the products tested have a rate inhibition constant of the same order of magnitude of $\alpha-\mathrm{TOH}$, indicating they are all potent chain breaking antioxidants. The number of peroxyl radicals 
trapped by each antioxidant $(n)$ is approximately 2 demonstrating that the mechanism of neutralization of radicals is also analogous to that of $\alpha-\mathrm{TOH}$.

In more details it is confirmed also that moving from dihydrobenzo[b]thiophenes 5 (Table 4 entries 2-4) to dihydrobenzo[b]thiophenes 6 (Table 4 entries 5-7) there is a solid increasing of $k_{\text {inh }}$ that allowed to consider a benzo $[b]$ thiophene ring as the more efficient residue to insert in ortho position to $\mathrm{OH}$ group for increasing the chain breaking antioxidant activity of a phenolic compound.

\section{Conclusions}

In this paper we reported a study dedicated to elucidating the scope of the acid promoted transposition of benzoxathiines into dihydrobenzo[b]thiophenes and benzo[b]thiophenes, the latter obtainable directly from oxathiines or from the dihydro- derivatives. The structural features on both $\mathrm{C} 2$ and benzofused aromatic ring of benzoxathiines required to allow the first and the second transposition have been clarified and exploited for the preparation of potent phenolic chain breaking antioxidants. The peculiar ability of the benzothiophene sulfur atom in promoting the $\mathrm{H}^{\bullet}$ atom transfer process from the ortho $\mathrm{OH}$ group to a peroxyl radical (ROO ${ }^{\bullet}$ ) has been confirmed. In fact, derivatives 5 and 6 showed kinetic constants $\left(k_{\text {inh }}\right)$ in the reaction with ROO' similar or superior to that of $\alpha-\mathrm{TOH}$, the more potent natural lipophilic antioxidant known.

We are now applying these results for the preparation of benzoxathiine derivatives to be used as a "reservoir" of potent antioxidants being unreactive towards oxidant radical species under neutral or basic conditions, but very reactive under acid conditions. The aim is to exploit these derivatives in peculiar physiologic conditions such as those cancer cells experiencing a hypoxic and low pH environment.

\section{Experimental Section}

General. ${ }^{1} \mathrm{H}$ and ${ }^{13} \mathrm{C}$ NMR spectra were recorded with Varian Mercury Plus 400, using $\mathrm{CDCl}_{3}$ as solvent. Residual $\mathrm{CHCl}_{3}$ at $7.26 \mathrm{ppm}$ and central line of $\mathrm{CDCl}_{3}$ at $77.00 \mathrm{ppm}$ were used as the reference of ${ }^{1} \mathrm{H}$ and ${ }^{13} \mathrm{C}$ NMR spectra respectively. FT-IR spectra were recorded with Spectrum Two FT-IR Spectrometer. GC-MS spectra were recorded with a QMD 100 Carlo Erba. ESI-MS spectra were recorded with a JEOL MStation JMS700. Melting points were measured with Stuart SMP50 Automatic Melting Point Apparatus. All the reactions were monitored by TLC on commercially available precoated plates (silica gel $60 \mathrm{~F} 254$ ) and the products were visualized with acidic vanillin solution. Silica gel 60 (230-400 mesh) was used for column chromatography. Dry solvents were obtained by The PureSolv Micro Solvent Purification System. Chloroform was washed with water several times and stored over calcium chloride. Pyridine and TEA were freshly distilled over $\mathrm{KOH}$. Phthalimide sulfenyl chloride was prepared from the corresponding commercially available disulfide (purchased from Chemper snc) as reported elsewhere. Reagents were purchased at the highest commercial quality and used without further purification, unless otherwise stated.

General cycloaddition procedure for the synthesis of derivatives 4. To a solution of derivatives 2 in $\mathrm{CHCl}_{3}(0.1$ M), was added the dienophile 3 ( 3 eq.) and triethylamine (1 eq.). The reaction mixture was left stirring at $60{ }^{\circ} \mathrm{C}$ until TLC analysis indicated complete consumption of the starting material, then was diluted with $\mathrm{CH}_{2} \mathrm{Cl}_{2}$, washed once with a saturated solution of $\mathrm{NH}_{4} \mathrm{Cl}$. The organic layer was dried over $\mathrm{Na}_{2} \mathrm{SO}_{4}$, filtered and evaporated in vacuo. 
4ad. From 2a (571 mg, $1.81 \mathrm{mmol}$ ). The crude was purified by silica gel column chromatography, using a mixture of petroleum ether and $\mathrm{CH}_{2} \mathrm{Cl}_{2}$ 2:1 as eluent. The purified product was obtained as pale yellow solid (150 mg, 30\% yield) mp 93-95 ${ }^{\circ} \mathrm{C} .{ }^{1} \mathrm{H} \mathrm{NMR}\left(400 \mathrm{MHz}, \mathrm{CDCl}_{3}\right) \delta 7.60-7.29(\mathrm{~m}, 5 \mathrm{H})$, 6.52 (s, 2H), 5.15 (bd, J $9.4 \mathrm{~Hz}, 1 \mathrm{H}), 3.75(\mathrm{~s}, 3 \mathrm{H}), 3.25$ (dd, J 12.9, $9.4 \mathrm{~Hz}, 1 \mathrm{H}), 3.11$ (dd, J 12.9, $1.6 \mathrm{~Hz}, 1 \mathrm{H}), 2.22$ (s, 3H). ${ }^{13} \mathrm{C} \mathrm{NMR}\left(100 \mathrm{MHz}, \mathrm{CDCl}_{3}\right) \delta$ 153.3, 144.6, 140.7, 128.9, 128.7, 128.2, 125.8, 117.1, 114.0, 108.4, 76.2, 55.6, 32.3, 16.5. Elemental Analysis Calcd for $\mathrm{C}_{16} \mathrm{H}_{16} \mathrm{O}_{2} \mathrm{~S}$ : C 70.56, H 5.92; found C 70.64, H 5.97.

4ae. From 2a (446 mg, $1.42 \mathrm{mmol}$ ). The crude was purified by silica gel column chromatography, using a mixture of petroleum ether and $\mathrm{CH}_{2} \mathrm{Cl}_{2} 1: 7$ as eluent. The purified product was obtained as light brown solid (216 mg, yield 64\%) mp 34-38 ${ }^{\circ} \mathrm{C} .{ }^{1} \mathrm{H}$ NMR $\left(400 \mathrm{MHz}, \mathrm{CDCl}_{3}\right) \delta 6.55-6.39(\mathrm{~m}, 2 \mathrm{H}), 5.35(\mathrm{dd}, J 5.0,2.3 \mathrm{~Hz}$, $1 \mathrm{H}), 4.07-3.81(\mathrm{~m}, 1 \mathrm{H}), 3.79-3.60\left(\mathrm{~s}+\mathrm{m}, 4 \mathrm{H},-\mathrm{OCH}_{3}\right), 3.14(\mathrm{dd}, J 12.7,2.3 \mathrm{~Hz}, 1 \mathrm{H}), 3.00(\mathrm{dd}, J 12.7,5.0 \mathrm{~Hz}, 1 \mathrm{H})$, $2.19(\mathrm{~s}, 3 \mathrm{H}), 1.25$ (t, J 7.1 Hz, 3H). ${ }^{13} \mathrm{C}$ NMR (100 MHz, $\left.\mathrm{CDCl}_{3}\right) \delta$ 153.4, 141.7, 128.9, 117.9, 114.1, 108.4, 94.7, 64.1, 55.5, 29.6, 16.3, 15.0. Elemental Analysis Calcd for $\mathrm{C}_{12} \mathrm{H}_{16} \mathrm{O}_{3} \mathrm{~S}$ : C 59.98, H 6.71; found C 59.84, H 6.85.

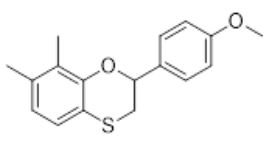

4ba. From $2 a(411 \mathrm{mg}, 1.38 \mathrm{mmol})$. The crude was purified by silica gel column chromatography, using a mixture of petroleum ether and $\mathrm{CH}_{2} \mathrm{Cl}_{2}$ 3:1 as eluent. The purified product was obtained as white solid (280 mg, yield 71\%) mp 94-96 ${ }^{\circ} \mathrm{C} .{ }^{1} \mathrm{H} \mathrm{NMR}\left(400 \mathrm{MHz}, \mathrm{CDCl}_{3}\right) \delta 7.38-7.35(\mathrm{~m}, 2 \mathrm{H}), 6.98$ $-6.93(\mathrm{~m}, 2 \mathrm{H}), 6.87(\mathrm{~d}, J 8.4 \mathrm{~Hz}, 1 \mathrm{H}), 6.71(\mathrm{~d}, J 8.4 \mathrm{~Hz}, 1 \mathrm{H}), 5.15(\mathrm{dd}, J$ 9.6, $2.0 \mathrm{~Hz}, 1 \mathrm{H}), 3.84(\mathrm{~s}, 3 \mathrm{H}), 3.21(\mathrm{dd}, J$ 13.2, $9.6 \mathrm{~Hz}, 1 \mathrm{H}) 3.06(\mathrm{dd}, J 13.2,2.0 \mathrm{~Hz}, 1 \mathrm{H}), 2.23(\mathrm{~s}, 3 \mathrm{H}), 2.14(\mathrm{~s}, 3 \mathrm{H}) .{ }^{13} \mathrm{C} \mathrm{NMR}\left(100 \mathrm{MHz}, \mathrm{CDCl}_{3}\right) \delta 159.5$, 150.2, 134.2, 133.3, 127.3, 127.0, 126.2, 123.8, 122.7, 114.0, 76.4, 55.3, 32.0, 19.8, 11.8. Elemental Analysis Calcd for $\mathrm{C}_{17} \mathrm{H}_{18} \mathrm{O}_{2} \mathrm{~S}$ : C 71.30, H 6.34; found C 69.84, $\mathrm{H} 6.15$.

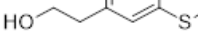

4ca. From 2c (144 mg, $0.46 \mathrm{mmol})$. The crude was purified by silica gel column chromatography, using a mixture of $\mathrm{CH}_{2} \mathrm{Cl}_{2}$ and AcOEt 20:1 as eluent. The purified product was obtained as colouless oil (79 mg, 57\% yield). ${ }^{1} \mathrm{H}-\mathrm{NMR}(400 \mathrm{MHz}, \mathrm{CDCl} 3) \delta 2.77(\mathrm{t}, J 2.0 \mathrm{~Hz}, 2 \mathrm{H}), 3.04(\mathrm{dd}, J 6.3,1.0 \mathrm{~Hz}, 1 \mathrm{H})$, $3.27(\mathrm{dd}, J 6.3,4.8 \mathrm{~Hz}, 1 \mathrm{H}), 3.78-3.86(\mathrm{~m}, 5 \mathrm{H}), 5.1(\mathrm{dd}, \mathrm{J} 4.8,1.0 \mathrm{~Hz}, 1 \mathrm{H}), 6.85-6.89(\mathrm{~m}, 2 \mathrm{H}), 6.92-6.96(\mathrm{~m}, 2 \mathrm{H})$, 6.97-6.99 (m, 1H), 7.31-7.34 (m, 2H). 13C-NMR (100 MHz, CDCl3) ס: 31.7, 38.2, 55.3, 63.6, 114.1, 117.2, 118.8, 126.2, 127.3, 127.4, 131.6, 132.4, 151.2, 159.7. Elemental Analysis Calcd for $\mathrm{C}_{17} \mathrm{H}_{18} \mathrm{O}_{3} \mathrm{~S}: \mathrm{C} 67.52$, $\mathrm{H}$ 6.00; found C 67.58, H 6.05 .

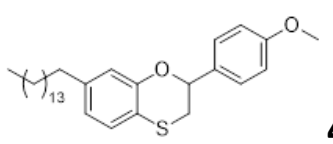

4da. From 2d (103 mg, $0.38 \mathrm{mmol})$. The crude was purified by silica gel column chromatography, using a mixture of petroleum ether and $\mathrm{CH}_{2} \mathrm{Cl}_{2}$ 6:1 as eluent. The purified product was obtained as colouless oil (110 mg, 62\% yield). ${ }^{1} \mathrm{H}-\mathrm{NMR}(400 \mathrm{MHz}, \mathrm{CDCl} 3) \delta$ 0.85-0.93 (m, 3H), 1.22-1.35 (m, $26 \mathrm{H}$ ), 2.45-2.57 (at, 2H), 3.03 (dd, J 13.1, $2.0 \mathrm{~Hz}, 1 \mathrm{H}$ ), 3.27 (dd, J 13.1, 9.6 Hz, 1H), 5.14 (dd, J 9.6, 2.0 Hz, 1H), 6.65-6.80 (m, 2H), 6.90-6.98 (m, 2H), $7.02(\mathrm{~d}, J 6.0 \mathrm{~Hz}, 1 \mathrm{H}), 7.30-7.40(\mathrm{~m}, 2 \mathrm{H})$. Elemental Analysis Calcd for $\mathrm{C}_{30} \mathrm{H}_{44} \mathrm{O}_{2} \mathrm{~S}$ : C 76.87, $\mathrm{H}$ 9.46; found C 76.90, H 9.51. 
4df. From 2d (589 mg, $1.22 \mathrm{mmol})$. The cis and trans products (cis-4df + trans-4df 60\% yield) were isolated after silica-gel column chromatography using a mixture of $\mathrm{CH}_{2} \mathrm{Cl}_{2}$ and petroleum ether $1: 3$ as eluent.

cis-4df white solid, $\mathrm{mp} 41-44^{\circ} \mathrm{C} .{ }^{1} \mathrm{H}-\mathrm{NMR}\left(400 \mathrm{MHz}, \mathrm{CDCl}_{3}\right) \delta: 0.85-0.93(\mathrm{~m}, 3 \mathrm{H}), 1.17-1.34(\mathrm{~m}, 29 \mathrm{H}), 1.37(\mathrm{~d}, \mathrm{~J}$ 3.4 Hz, 3H), 2.45-2.55 (pt, 2H), 3.36 (qd, J 3.4, 1.0 Hz, 1H), 3.72 (dq, J 5.1, 3.5 Hz, 1H), 3.93 (dq, J 5.1, $3.5 \mathrm{~Hz}$, $1 \mathrm{H}), 5.17$ (d, J $1.0 \mathrm{~Hz}), 6.68-6.72(\mathrm{~m}, 2 \mathrm{H}), 6.90-6.94(\mathrm{~m}, 1 \mathrm{H}) .{ }^{13} \mathrm{C}-\mathrm{NMR}\left(100 \mathrm{MHz}, \mathrm{CDCl}_{3}\right) \delta 14.1,15.0,15.4,22.7$, 29.2, 29.3, 29.5, 29.6 (2C), 29.7 (5C), 31.2, 31.9, 35.3, 36.2, 64.5, 97.1, 114.4, 118.2, 122.0, 126.6, 140.8, 148.5. trans-4df white solid, mp 41-42 ${ }^{\circ} \mathrm{C} .{ }^{1} \mathrm{H}-\mathrm{NMR}\left(400 \mathrm{MHz}, \mathrm{CDCl}_{3}\right) \delta:$ 0.85-0.93 (m, 3H), 1.18-1.34 (m, $\left.29 \mathrm{H}\right), 1.37(\mathrm{~d}$, J $3.4 \mathrm{~Hz}, 3 \mathrm{H}), 2.45-2.55$ (pt, 2H), $3.36(\mathrm{dq}, J 2.1,3.4 \mathrm{~Hz}, 1 \mathrm{H}), 3.72(\mathrm{dq}, J 5.0,3.6 \mathrm{~Hz}, 1 \mathrm{H}), 3.93(\mathrm{dq}, J 5.0,3.6 \mathrm{~Hz}$, $1 \mathrm{H}), 5.17$ (d, J $2.1 \mathrm{~Hz}), 6.68-6.72(\mathrm{~m}, 2 \mathrm{H}), 6.92-6.96(\mathrm{~m}, 1 \mathrm{H}){ }^{13} \mathrm{C}-\mathrm{NMR}\left(100 \mathrm{MHz}^{\mathrm{C}} \mathrm{CDCl}_{3}\right) \delta: 14.1,15.0,15.4,22.7$, 29.2, 29.3, 29.5, 29.6 (2C), 29.7 (5C), 31.2, 31.9, 35.3, 36.2, 64.5, 97.1, 114.4, 118.2, 122.0, 126.6, 140.8, 148.5.

4ea. From 2 e $(101 \mathrm{mg}, 0.20 \mathrm{mmol})$. The crude product was purified by silica-gel column chromatography with a mixture of petroleum ether: $\mathrm{CH}_{2} \mathrm{Cl}_{2}=3: 1$. The purified product was obtained as oil (37 mg, 36\% yield). ${ }^{1} \mathrm{H}$ NMR $\left(400 \mathrm{MHz}, \mathrm{CDCl}_{3}\right) \delta 7.35$ (d, J $\left.8.8 \mathrm{~Hz}, 2 \mathrm{H}\right), 6.94(\mathrm{~d}, J 8.8 \mathrm{~Hz}, 2 \mathrm{H}), 6.49(\mathrm{~s}, 2 \mathrm{H}), 5.08$ (dd, J 9.6, $1.8 \mathrm{~Hz}, 1 \mathrm{H}), 3.87(\mathrm{t}, J 6.6 \mathrm{~Hz}, 2 \mathrm{H}), 3.83(\mathrm{~s}, 3 \mathrm{H}), 3.22(\mathrm{dd}, J 12.9,9.6 \mathrm{~Hz}, 1 \mathrm{H}), 3.05$ (dd, J $12.9,1.9 \mathrm{~Hz}$, $1 \mathrm{H}), 2.17(\mathrm{~s}, 3 \mathrm{H}), 1.77-1.70(\mathrm{~m}, 2 \mathrm{H}), 1.44-1.39(\mathrm{~m}, 2 \mathrm{H}), 1.35-1.26(\mathrm{~m}, 20 \mathrm{H}), 0.88(\mathrm{t}, J 6.6 \mathrm{~Hz}, 3 \mathrm{H}) .{ }^{13} \mathrm{C} \mathrm{NMR}$ $\left(100 \mathrm{MHz}_{1} \mathrm{CDCl}_{3}\right) \delta 159.5,152.8,144.6,133.0,128.8,127.0,117.0,114.5,114.0,109.2,68.5,55.3,32.3,31.9$, 30.9, 29.7, 29.6, 29.4, 29.3 (4 signals for 9 non-equivalent $\mathrm{CH}_{2}$ groups), 26.0, 22.7, 16.4, 14.1. Elemental Analysis Calcd for $\mathrm{C}_{30} \mathrm{H}_{44} \mathrm{O}_{3} \mathrm{~S}$ : C 74.33, H 9.15; found C 74.38, H 9.19.

4eb. From 2e $(100 \mathrm{mg}, 0.20 \mathrm{mmol})$. The crude product was purified by silica-gel flash chromatography with a mixture of petroleum ether : $\mathrm{CH}_{2} \mathrm{Cl}_{2}=3: 1$ as eluent. The purified product was obtained as oil (37 mg 37\% yield). ${ }^{1} \mathrm{H} \mathrm{NMR}\left(400 \mathrm{MHz}, \mathrm{CDCl}_{3}\right) \delta 7.28(\mathrm{~d}, J 8.6 \mathrm{~Hz}, 2 \mathrm{H}), 6.94(\mathrm{~d}, J 8.6 \mathrm{~Hz}, 2 \mathrm{H}), 6.48$ $(\mathrm{s}, 2 \mathrm{H}), 4.61(\mathrm{~d}, J 8.6 \mathrm{~Hz}, 1 \mathrm{H}), 3.87(\mathrm{t}, J 6.6 \mathrm{~Hz}, 2 \mathrm{H}), 3.84(\mathrm{~s}, 3 \mathrm{H}), 3.46-3.38(\mathrm{~m}, 1 \mathrm{H}), 2.12(\mathrm{~s}, 3 \mathrm{H}), 1.78-1.71$ $(\mathrm{m}, 2 \mathrm{H}), 1.45-1.40(\mathrm{~m}, 2 \mathrm{H}), 1.33-1.28(\mathrm{~m}, 2 \mathrm{H}), 1.09+1.07(\mathrm{~s}, 3 \mathrm{H}), 0.91-0.88(\mathrm{~m}, 3 \mathrm{H}) .{ }^{13} \mathrm{C} \mathrm{NMR}(100 \mathrm{MHz}$, CDCl3) $\delta 159.6,152.9,144.7,131.3,128.4,128.3,118.9,114.2,113.9,108.7,82.5,68.5,55.2,38.9,31.9,29.7$, 29.6, 29.4 (3 signals for 9 non-equivalent $\mathrm{CH}_{2}$ groups), 26.0, 22.7, 17.6, 16.5, 14.1. Elemental Analysis Calcd for $\mathrm{C}_{31} \mathrm{H}_{46} \mathrm{O}_{3} \mathrm{~S}$ : C 74.65, H 9.30; found C 74.70, H 9.34.

4ee. From 2e (150 $\mathrm{mg}, 0.30 \mathrm{mmol})$. The crude product was purified by silica-gel column chromatography with a mixture of petroleum ether and $\mathrm{CH}_{2} \mathrm{Cl}_{2} \quad 3: 1$ as eluent. The purified product was obtained as a pale yellow oil (37 mg, 53\% yield). ${ }^{1} \mathrm{H}$ NMR $\left(400 \mathrm{MHz}, \mathrm{CDCl}_{3}\right) \delta 6.49-6.45(\mathrm{~m}, 2 \mathrm{H}), 5.34(\mathrm{dd}, J$ 5.0, $2.2 \mathrm{~Hz}, 1 \mathrm{H}), 3.97-3.89(\mathrm{~m}, 1 \mathrm{H}), 3.45(\mathrm{t}, J 6.6 \mathrm{~Hz}, 2 \mathrm{H}), 3.75-3.68(\mathrm{~m}, 1 \mathrm{H}), 3.14(\mathrm{dd}, J 12.7,2.2 \mathrm{~Hz}, 1 \mathrm{H}), 3.00$ $(\mathrm{dd}, J 12.7,5.0 \mathrm{~Hz}, 1 \mathrm{H}), 2.18(\mathrm{~s}, 3 \mathrm{H}), 1.76-1.69(\mathrm{~m}, 2 \mathrm{H}), 1.44-1.40(\mathrm{~m}, 2 \mathrm{H}), 1.34-1.24(\mathrm{~m}, 23 \mathrm{H}), 0.88(\mathrm{t}, J 6.6$ $\mathrm{Hz}, 3 \mathrm{H}) .{ }^{13} \mathrm{C} \mathrm{NMR}\left(100 \mathrm{MHz}, \mathrm{CDCl}_{3}\right) \delta 153.0,141.6,128.8,120.7,117.8,114.8,109.2,94.8,68.4,64.1,31.9$, 29.6, 29.4, 29.3 (3 signals for 9 non-equivalent $\mathrm{CH}_{2}$ groups), 26.0, 22.7, 16.3, 15.0, 14.1. Elemental Analysis Calcd for $\mathrm{C}_{25} \mathrm{H}_{42} \mathrm{O}_{3} \mathrm{~S}$ : C 71.04, $\mathrm{H}$ 10.02; found C 71.07, $\mathrm{H} 10.04$. 
4fb. From $2 \mathrm{f}$ ( $206 \mathrm{mg}, 0.40 \mathrm{mmol})$. The crude product was purified by silica-gel column chromatography using a mixture of $\mathrm{CH}_{2} \mathrm{Cl}_{2}$ and petroleum ether $1: 1$ as eluent. The purified product was obtained as yellow oil (70 mg, 37\%). ${ }^{1} \mathrm{H}$ NMR $\left(400 \mathrm{MHz}, \mathrm{CDCl}_{3}\right) \delta 7.28(\mathrm{~d}, J 8.8 \mathrm{~Hz}, 2 \mathrm{H}), 6.93(\mathrm{~d}, J 8.8 \mathrm{~Hz}, 2 \mathrm{H})$, $6.60(\mathrm{~d}, J 2.9 \mathrm{~Hz}, 1 \mathrm{H}), 6.50(\mathrm{~d}, J 2.9 \mathrm{~Hz}, 1 \mathrm{H}), 4.40(\mathrm{~d}, J 9.1 \mathrm{~Hz}, 1 \mathrm{H}), 3.87(\mathrm{t}, J 6.6 \mathrm{~Hz}, 2 \mathrm{H}), 3.84(\mathrm{~s}, 3 \mathrm{H}), 3.56(\mathrm{dd}, J$ 9.1, $6.6 \mathrm{~Hz}, 1 \mathrm{H}), 1.77-1.73(\mathrm{~m}, 2 \mathrm{H}), 1.46-1.42(\mathrm{~m}, 2 \mathrm{H}), 1.36-1.27(\mathrm{~m}, 22 \mathrm{H}), 1.24(\mathrm{~s}, 9 \mathrm{H}), 0.88(\mathrm{t}, J 6.6 \mathrm{~Hz}$, $3 \mathrm{H}) .{ }^{13} \mathrm{C} \mathrm{NMR}\left(100 \mathrm{MHz}, \mathrm{CDCl}_{3}\right) \delta 159.6,153.2,145.9,141.0,131.0,128.3,120.8,113.9,111.2,107.7,82.4$, 68.4, 55.2, 39.8, 35.0, 31.9, 30.9, 29.7, 29.6, 29.4 (2 signals for 9 non-equivalent $\mathrm{CH}_{2}$ groups), 26.1, 22.7, 17.9, 14.1. MS m/z (Irel, \%): 419 (31.29); 148 (100.00). Elemental Analysis Calcd for $\mathrm{C}_{34} \mathrm{H}_{52} \mathrm{O}_{3} \mathrm{~S}: \mathrm{C} 75.51, \mathrm{H} 9.69 ;$ found C 75.57, H 9.74 .

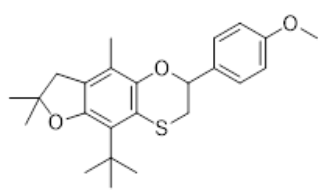

4ga. From $2 \mathrm{~g}$ (140 mg, $0.34 \mathrm{mmol}$ ). The crude was purified by silica-gel column chromatography, using a mixture of petroleum ether and $\mathrm{CH}_{2} \mathrm{Cl}_{2}$ 2:1 as eluent. The purified product was obtained an incolor oil $\left(80 \mathrm{mg}, 59 \%\right.$ yield). ${ }^{1} \mathrm{H}$ NMR $\left(400 \mathrm{MHz}, \mathrm{CDCl}_{3}\right) \delta 7.36(\mathrm{~d}, J 8.7 \mathrm{~Hz}, 2 \mathrm{H}), 6.93(\mathrm{~d}, J 8.7 \mathrm{~Hz}$, 2H), 5.19 (dd, J 9.2, $3.6 \mathrm{~Hz}, 1 \mathrm{H}$ ), $3.83(\mathrm{~s}, 3 \mathrm{H}), 3.08$ (dd, J 12.9, $3.6 \mathrm{~Hz}, 1 \mathrm{H}), 2.99$ (dd, J 12.9, $9.2 \mathrm{~Hz}, 1 \mathrm{H}), 2.84(\mathrm{~s}$, 2H), 2.05 (s, 3H), $1.58(\mathrm{~s}, 9 \mathrm{H}), 1.45(\mathrm{~s}, 3 \mathrm{H}), 1.44(\mathrm{~s}, 3 \mathrm{H}) .{ }^{13} \mathrm{C} \mathrm{NMR}\left(100 \mathrm{MHz}, \mathrm{CDCl}_{3}\right) \delta$ 159.4, 151.3, 145.8, 133.8, 127.2, 126.1, 125.9, 122.8, 119.0, 113.9, 84.2, 77.9, 55.3, 41.9, 37.7, 34.6, 31.7, 28.3, 13.4. Elemental Analysis Calcd for $\mathrm{C}_{24} \mathrm{H}_{30} \mathrm{O}_{3} \mathrm{~S}: \mathrm{C} 72.33, \mathrm{H} 7.59$; found C 72.37, H 9.63.

General procedure for transposition. A solution of 4 or 5 and acid $\left(\mathrm{BF}_{3} \cdot \mathrm{OEt}_{2}\right.$ or $\left.\mathrm{CF}_{3} \mathrm{SO}_{3} \mathrm{H}\right)$ in dry $\mathrm{CHCl}_{3}(0.03 \mathrm{M})$ was left under magnetic stirring at r.t. or $60{ }^{\circ} \mathrm{C}$ until complete consumption of the starting material as monitored by TLC. The solution was then diluted with $\mathrm{CH}_{2} \mathrm{Cl}_{2}(30 \mathrm{~mL})$ and washed with a saturated solution of $\mathrm{NaHCO}_{3}(2 \times 30 \mathrm{~mL})$ and $\mathrm{H}_{2} \mathrm{O}(2 \times 30 \mathrm{~mL})$. The organic layer was dried over anhydrous $\mathrm{Na}_{2} \mathrm{SO}_{4}$ and concentrated in vacuum. The crude was purified by silica gel column chromatography to yield the desired dihydrobenzo[b]thiophene 5 or benzothiophene 6 .

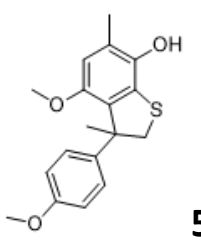

5ac. The reaction carried out following the general procedure from $4 a c(40 \mathrm{mg}, 0.13 \mathrm{mmol})$ using $\mathrm{BF}_{3} \mathrm{Et}_{2} \mathrm{O}$ (3 equiv.) at $60^{\circ} \mathrm{C}$ for $30 \mathrm{~min}$. The crude was purified by silica gel column chromatography $\left(\mathrm{CH}_{2} \mathrm{Cl}_{2}\right.$ as eluent) to yield the desired product 5ac as light orange solid $\left.\mathrm{mp} 111-113{ }^{\circ} \mathrm{C} \mathrm{(27} \mathrm{mg,} \mathrm{yield} 66 \%\right)$ and $16 \%$ benzo[ $b]$ thiophene $6 a .{ }^{1} \mathrm{H}$ NMR $\left(400 \mathrm{MHz}, \mathrm{CDCl}_{3}\right) \delta 7.19-7.17(\mathrm{~m}, 2 \mathrm{H}), 6.82-6.80(\mathrm{~m}, 2 \mathrm{H}), 6.41(\mathrm{~s}, 1 \mathrm{H}), 3.78$ (s, 3H), $3.50-3.40(\mathrm{~m}, 5 \mathrm{H}), 2.25(\mathrm{~s}, 3 \mathrm{H}), 1.85(\mathrm{~s}, 3 \mathrm{H}) .{ }^{13} \mathrm{C} \mathrm{NMR}\left(100 \mathrm{MHz}, \mathrm{CDCl}_{3}\right) \delta$ 157.9, 150.5, 142.2, 138.8, 132.7, 129.3, 127.0, 124.2, 113.3, 111.7, 56.0, 55.8, 55.2, 50.0, 24.9, 15.9. FT-IR $\left(\mathrm{CCl}_{4} 0.05 \mathrm{M}, \mathrm{cm}^{-1}\right) \vee 3615$, $3572,3000,2934,2834,1717,1610,1583,1511,1484,1464,1400,1248,1182$. Elemental Analysis Calcd for $\mathrm{C}_{18} \mathrm{H}_{20} \mathrm{O}_{3} \mathrm{~S}$ : C 68.33, H 6.37; found C 68.47, H 6.51. 
6a. The reaction carried out following the general procedure from 4ac $(51 \mathrm{mg}, 0.16 \mathrm{mmol})$ using $\mathrm{CF}_{3} \mathrm{SO}_{3} \mathrm{H}$ (1 equiv.) at $60^{\circ} \mathrm{C}$ for $20 \mathrm{~min}$. The crude was purified by silica gel column chromatograph (petroleum ether: $\mathrm{CH}_{2} \mathrm{Cl}_{2}$ 1:1 as eluent) and the second, on the mixed fraction containing the desired product, using a mixture of petroleum ether and $\mathrm{CH}_{2} \mathrm{Cl}_{2} 1: 1$. The purified product was obtained as brown oil (15 mg, yield $46 \%$ ). IR $\left(\mathrm{CCl}_{4} 0.05 \mathrm{M}, \mathrm{cm}^{-1}\right) \vee 3614,3590,2925,2845,1655,1614,1529,1485,1464,1173 .{ }^{1} \mathrm{H} \mathrm{NMR}\left(400 \mathrm{MHz} \mathrm{CDCl}_{3}\right)$ $\delta 6.80(\mathrm{~d}, J 1.2 \mathrm{~Hz}, 1 \mathrm{H}), 6.51(\mathrm{~s}, 1 \mathrm{H}), 4.46(\mathrm{bs}, 1 \mathrm{H}), 3.85(\mathrm{~s}, 3 \mathrm{H}), 2.56(\mathrm{~d}, J 1.2 \mathrm{~Hz}, 3 \mathrm{H}), 2.35(\mathrm{~s}, 3 \mathrm{H}) .{ }^{13} \mathrm{C} \mathrm{NMR}(100$ $\left.\mathrm{MHz}_{2} \mathrm{CDCl}_{3}\right) \delta 150.9,141.7,134.1,131.2,129.2,119.2,117.6,108.3,55.9,17.3,15.6$. Elemental Analysis Calcd for $\mathrm{C}_{11} \mathrm{H}_{12} \mathrm{O}_{2} \mathrm{~S}$ : C 63.44, H 5.81; found C 63.49, H 5.85 .

5ad. The reaction carried out following the general procedure from 4 ad ( $25 \mathrm{mg}, 0.09 \mathrm{mmol}$ ) using $\mathrm{CF}_{3} \mathrm{SO}_{3} \mathrm{H}$ (5 equiv.) at $60^{\circ} \mathrm{C}$ for $7 \mathrm{~h}$. The crude was purified by silica gel column chromatography (petroleum ether: $\mathrm{CH}_{2} \mathrm{Cl}_{2} 1: 1$ as eluent) to yield the desired product as a brown oil (6 mg, yield $\left.25 \%\right) .{ }^{1} \mathrm{H} \mathrm{NMR}(400 \mathrm{MHz}$, $\left.\mathrm{CDCl}_{3}\right) \delta 7.28-7.05(\mathrm{~m}, 5 \mathrm{H}), 6.31(\mathrm{~s}, 1 \mathrm{H}), 4.74(\mathrm{dd}, J 8.5,2.1 \mathrm{~Hz}, 1 \mathrm{H}), 4.10(\mathrm{~s}, 1 \mathrm{H}), 3.97-3.78(\mathrm{~m}, 1 \mathrm{H}), 3.50(\mathrm{~s}$, 3H), 3.22 (dd, J 11.1, $2.1 \mathrm{~Hz}, 1 \mathrm{H}), 2.18(\mathrm{~s}, 3 \mathrm{H}) .{ }^{13} \mathrm{C} \mathrm{NMR}\left(100 \mathrm{MHz}, \mathrm{CDCl}_{3}\right) \delta 150.2,142.7,142.2,129.6,128.6$, $128.3,127.1,126.7,124.5,110.6,55.9,50.7,42.9,16.0$. IR $\left(\mathrm{CCl}_{4} 0.025 \mathrm{M}, \mathrm{cm}^{-1}\right) \vee 3614,3576,3063,3028,3001$, $2932,2854,2833,1602,1593,1490,1464,1453,1405,1186,1034$. Elemental Analysis Calcd for $\mathrm{C}_{16} \mathrm{H}_{16} \mathrm{O}_{2} \mathrm{~S}: \mathrm{C}$ 70.56, H 5.92; found C 70.61, H 5.97.

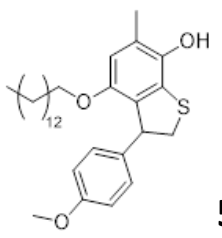

5ea. The reaction carried out following the general procedure from 4 ea ( $30 \mathrm{mg}, 0.06 \mathrm{mmol}$ ) using $\mathrm{BF}_{3} \mathrm{Et}_{2} \mathrm{O}$ ( 3 equiv.) at $60^{\circ} \mathrm{C}$ for $3 \mathrm{~h}$. The crude product was purified by silica-gel column chromatography (petroleum ether: $\mathrm{CH}_{2} \mathrm{Cl}_{2}$ 1:2 as eluent) obtaining the purified product 5 ea as a beige oil (15 mg, yield $53 \%$ ). ${ }^{1} \mathrm{H}$ NMR $\left(400 \mathrm{MHz}, \mathrm{CDCl}_{3}\right) \delta 7.16(\mathrm{~d}, J 8.6 \mathrm{~Hz}, 2 \mathrm{H}), 6.78(\mathrm{~d}, J 8.6 \mathrm{~Hz}, 2 \mathrm{H}), 6.34(\mathrm{~s}, 1 \mathrm{H}), 4.76(\mathrm{dd}, J 8.5,2.8 \mathrm{~Hz}, 1 \mathrm{H})$, $4.18(\mathrm{~s}, 1 \mathrm{H}), 3.92(\mathrm{dd}, J 11.1,8.5 \mathrm{~Hz}, 1 \mathrm{H}), 3.81-3.75(\mathrm{~m}, 1 \mathrm{H}), 3.76(\mathrm{~s}, 3 \mathrm{H}), 3.66-3.60(\mathrm{~m}, 1 \mathrm{H}), 3.26(\mathrm{dd}, J 11.1$, $2.8 \mathrm{~Hz}, 1 \mathrm{H}), 2.23(\mathrm{~s}, 3 \mathrm{H}), 1.52-1.45(\mathrm{~m}, 2 \mathrm{H}), 1.30-1.17(\mathrm{~m}, 22 \mathrm{H}), 0.88(\mathrm{t}, J 6.62 \mathrm{~Hz}, 3 \mathrm{H}) .{ }^{13} \mathrm{C} \mathrm{NMR}(100 \mathrm{MHz}$, $\left.\mathrm{CDCl}_{3}\right) \delta 158.3,149.6,142.0,135.4,130.0,129.2,128.1,124.3,113.6,111.5,68.5,55.2,50.3,42.7,31.9,29.71$, 29.70, 29.68, 29.66, 29.63, 29.55, 29.4, 29.3, 29.2, 25.8, 22.7, 16.0, 14.1. IR $\left(\mathrm{CDCl}_{3}, 0.05 \mathrm{M}, \mathrm{cm}^{-1}\right) \vee 3603,2927$, $2855,1609,1511,1487,1468,1407,1245,1179$. Elemental Analysis Calcd for $\mathrm{C}_{30} \mathrm{H}_{44} \mathrm{O}_{3} \mathrm{~S}: \mathrm{C} 74.33, \mathrm{H} 9.15$; found C 74.37, H 9.18.

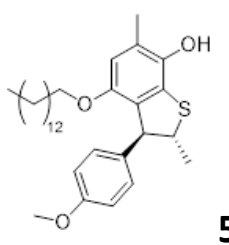

5eb. The reaction carried out following the general procedure from 4eb ( $35 \mathrm{mg}, 0.07 \mathrm{mmol}$ ) using $\mathrm{BF}_{3} . \mathrm{Et}_{2} \mathrm{O}$ (3 equiv.) at $60^{\circ} \mathrm{C}$ for $1 \mathrm{~h}$. The crude product was purified by silica-gel column chromatography (petroleum ether: $\mathrm{CH}_{2} \mathrm{Cl}_{2}$ 1:2 as eluent) obtaining the purified product 5eb as light orange oil (22 mg, yield 
63\%). ${ }^{1} \mathrm{H}$ NMR (400 MHz, $\left.\mathrm{CDCl}_{3}\right) \delta 7.12(\mathrm{~d}, \mathrm{~J} 8.7 \mathrm{~Hz}, 2 \mathrm{H}), 6.77(\mathrm{~d}, J 8.7 \mathrm{~Hz}, 2 \mathrm{H}), 6.35(\mathrm{~s}, 1 \mathrm{H}), 4.32(\mathrm{~d}, J 3.1 \mathrm{~Hz}, 1 \mathrm{H})$, 4.16 (bs, 1H), $3.80-3.70(\mathrm{~m}, 2 \mathrm{H}), 3.76(\mathrm{~s}, 3 \mathrm{H}), 3.63-3.57(\mathrm{~m}, 1 \mathrm{H}), 2.23(\mathrm{~s}, 3 \mathrm{H}), 1.53+1.52(\mathrm{~s}, 3 \mathrm{H}), 1.48-1.41$ $(\mathrm{m}, 2 \mathrm{H}), 1.31-1.12(\mathrm{~m}, 22 \mathrm{H}), 0.89(\mathrm{t}, J 6.6 \mathrm{~Hz}, 3 \mathrm{H}) .{ }^{13} \mathrm{C} \mathrm{NMR}\left(100 \mathrm{MHz}, \mathrm{CDCl}_{3}\right) \delta 158.3,150.1,142.1,135.1$, $128.8,128.3,128.1,124.2,113.6,111.7,68.6,58.9,55.2,54.8,31.9,29.71,29.70,29.68,29.66,29.65,29.55$, 29.36, 29.34, 29.23, 25.8, 23.7, 22.7, 16.0, 14. IR $\left(\mathrm{CDCl}_{3}, 0.05 \mathrm{M}, \mathrm{cm}^{-1}\right) \vee 3571,2928,2856,1610,1511,1488$, $1468,1408,1304,1245,1178,1108,1036$. MS (ESI): $\mathrm{m} / 2497.3$ [M-H]'. Elemental Analysis Calcd for $\mathrm{C}_{31} \mathrm{H}_{46} \mathrm{O}_{3} \mathrm{~S}$ : C 74.65, H 9.30; found C 74.68, H 9.35.

6b. The reaction carried out following the general procedure from 4 ee $(20 \mathrm{mg}, 0.047 \mathrm{mmol})$ using $\mathrm{CF}_{3} \mathrm{SO}_{3} \mathrm{H}$ (0.5 equiv.) at room temperature for $30 \mathrm{~min}$, was gradually heated to $30{ }^{\circ} \mathrm{C}\left(3 \mathrm{~h}\right.$ ) and then to $60{ }^{\circ} \mathrm{C}$ (1h). The crude was purified by silica gel column chromatography, using a mixture of petroleum ether and $\mathrm{CH}_{2} \mathrm{Cl}_{2}$ 1:2 as eluent. The purified product was obtained as a light brown oil (4 mg, yield $\left.23 \%\right)$. IR (CDCl $\left.0.05 \mathrm{M}, \mathrm{cm}^{-1}\right) \vee 3602,2928,2856,1466,1409,1262,1099 . \mathrm{MS}(\mathrm{ESI}): \mathrm{m} / \mathrm{z} 375.2[\mathrm{M}-\mathrm{H}]^{-} .{ }^{1} \mathrm{H} \mathrm{NMR}(400 \mathrm{MHz}$, $\left.\mathrm{CDCl}_{3}\right) \delta 7.44(\mathrm{~d}, J 5.8 \mathrm{~Hz}, 1 \mathrm{H}), 7.25(\mathrm{~d}, J 5.8 \mathrm{~Hz}, 1 \mathrm{H}), 6.54(\mathrm{~s}, 1 \mathrm{H}), 4.54(\mathrm{bs}, 1 \mathrm{H}), 4.04(\mathrm{t}, J 6.5 \mathrm{~Hz}, 2 \mathrm{H}), 2.36(\mathrm{~s}$, $3 \mathrm{H}), 1.87-1.80(\mathrm{~m}, 2 \mathrm{H}), 1.52-1.46(\mathrm{~m}, 2 \mathrm{H}), 1.26$ (bs, 20H), $0.90-0.86(\mathrm{~m}, 3 \mathrm{H}) .{ }^{13} \mathrm{C} \mathrm{NMR}\left(100 \mathrm{MHz}^{\mathrm{C}} \mathrm{CDCl}\right)_{3} \delta$ 148.6, 141.7, 135.0, 134.7, 123.8, 121.4, 117.8, 109.0, 68.9, 31.9, 29.7, 29.6, 29.4 (3 signals for 9 nonequivalent $\mathrm{CH}_{2}$ groups), 26.2, 22.7, 15.7, 14.1. Elemental Analysis Calcd for $\mathrm{C}_{23} \mathrm{H}_{36} \mathrm{O} 2 \mathrm{~S}: \mathrm{C} 73.35, \mathrm{H} 9.64 ;$ found C 73.38, H 9.69.

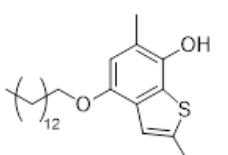

6c. The reaction carried out following the general procedure from 5 eb $(18 \mathrm{mg}, 0.036 \mathrm{mmol})$ using $\mathrm{CF}_{3} \mathrm{SO}_{3} \mathrm{H}$ (0.5 equiv.) at $60^{\circ} \mathrm{C}$ for $2 \mathrm{~h}$. The crude product was purified by silica-gel column chromatography (petroleum ether: $\mathrm{CH}_{2} \mathrm{Cl}_{2}$ 1:1 as eluent) obtaining a light brown oil (7 mg, yield 50\%). ${ }^{1} \mathrm{H} \mathrm{NMR}\left(400 \mathrm{MHz} \mathrm{CDCl}_{3}\right)$ $\delta 7.08(\mathrm{~s}, 1 \mathrm{H}), 6.50(\mathrm{~s}, 1 \mathrm{H}), 4.45$ (bs, 1H), 4.00 (t, J $6.5 \mathrm{~Hz}, 2 \mathrm{H}), 2.56(\mathrm{~s}, 3 \mathrm{H}), 2.33(\mathrm{~s}, 3 \mathrm{H}), 1.85-1.78(\mathrm{~m}, 2 \mathrm{H})$, $1.52-1.45(\mathrm{~m}, 2 \mathrm{H}), 1.35-1.26(\mathrm{~m}, 20 \mathrm{H}), 0.88(\mathrm{t}, J 6.7 \mathrm{~Hz}, 3 \mathrm{H}) .{ }^{13} \mathrm{C} \mathrm{NMR}(100 \mathrm{MHz}, \mathrm{CDCl} 3) \delta 147.8,141.3$, 138.4, 131.1, 129.2, 119.0, 117.0, 109.2, 68.9, 31.9, 29.7, 29.6, 29.5, 29.4 (4 signals for 9 non-equivalent $\mathrm{CH}_{2}$ groups), 26.2, 22.7, 16.1, 15.7, 14.1. IR ( $\left.\mathrm{CDCl}_{3}, 0.05 \mathrm{M}, \mathrm{cm}-1\right) \vee$ 3602, 2928, 2856, 1469, 1277, 1229, $1139,1039$. MS (ESI): $\mathrm{m} / \mathrm{z} 389.3$ [M-H]'. Elemental Analysis Calcd for $\mathrm{C}_{24} \mathrm{H}_{38} \mathrm{O}_{2} \mathrm{~S}: \mathrm{C} 73.80, \mathrm{H} 9.81$; found C 73.84, $\mathrm{H} 9.87$.

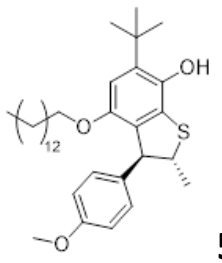

5fb. The reaction carried out following the general procedure from $4 \mathrm{fb}$ ( $34 \mathrm{mg}, 0.063 \mathrm{mmol}, 0.001$ $\mathrm{M}$ ) using $\mathrm{BF}_{3} . \mathrm{Et}_{2} \mathrm{O}$ (3 equiv.) at $60^{\circ} \mathrm{C}$ for $22 \mathrm{~h}$ after was added more $\mathrm{BF}_{3} . \mathrm{Et}_{2} \mathrm{O}$ (3 equiv.) and the reaction was left for additional $8 \mathrm{~h}$ at $60^{\circ} \mathrm{C}$. The crude was purified by silica-gel column chromatography using before a mixture of petroleum ether and $\mathrm{CH}_{2} \mathrm{Cl}_{2} 8: 1$ as eluent to $1: 1$ to obtain the desired product as an orange solid (15 mg, yield 45\%). ${ }^{1} \mathrm{H}$ NMR (400 MHz, CDCl3) $\delta 7.13(\mathrm{~d}, \mathrm{~J} 8.6 \mathrm{~Hz}, 2 \mathrm{H}), 6.79(\mathrm{~d}, \mathrm{~J} 8.6 \mathrm{~Hz}, 2 \mathrm{H}), 6.51(\mathrm{~s}, 1 \mathrm{H}), 4.32$ (d, J 3.7 $\mathrm{Hz}, 1 \mathrm{H}), 4.06(\mathrm{~s}, 1 \mathrm{H}), 3.80-3.75(\mathrm{~m}, 2 \mathrm{H}), 3.76(\mathrm{~s}, 3 \mathrm{H}), 3.63-3.58(\mathrm{~m}, 1 \mathrm{H}), 1.53+1.51(\mathrm{~s}, 3 \mathrm{H}), 1.47-1.43(\mathrm{~m}$, $2 \mathrm{H}), 1.40(\mathrm{~s}, 9 \mathrm{H}), 1.32-1.14(\mathrm{~m}, 22 \mathrm{H}), 0.88(\mathrm{t}, \mathrm{J} 6.6 \mathrm{~Hz}, 3 \mathrm{H}) .{ }^{13} \mathrm{C} \mathrm{NMR}(100 \mathrm{MHz}, \mathrm{CDCl} 3) \delta$ 158.3, 149.7, 142.5, 136.9, 135.0, 129.7, 128.6, 128.3, 113.6, 109.0, 68.7, 59.2, 55.2, 55.1, 34.9, 31.9, 29.7, 29.6, 29.4 (2 signals for 
9 non-equivalent $\mathrm{CH}_{2}$ ), 25.8, 23.2, 22.7, 14.1. Elemental Analysis Calcd for $\mathrm{C}_{34} \mathrm{H}_{52} \mathrm{O}_{3} \mathrm{~S}$ : C 75.51, $\mathrm{H}$ 9.69; found C 75.55, H 9.71.

\section{Acknowledgements}

We thank MIUR-Italy ("Progetto Dipartimenti di Eccellenza 2018-2022" allocated to Department of Chemistry "Ugo Schiff" and "Funding for basic activities related to research FFABR 2018".

\section{Supplementary Material}

Synthetic procedures and NMR spectra are available as supplementary material of this article.

\section{References}

1. Stubbe, J.; van Der Donk, W. A. Chem. Rev. 1998, 98, 705. https://doi.org/10.1021/cr9400875

2. Hensley, K.; Robinson, K. A.; Gabbita, S. P.; Salsman, S.; Floyd, R. A. Free Radic. Biol. Med. 2000, $28,1456$. https://doi.org/10.1016/S0891-5849(00)00252-5

3. Stubbe, J. J. Chem. Commun. 2003, 2511. https://doi.org/10.1039/b307617m

4 Halliwell, B.; Gutteridge, J. M. C. Antioxidants in Nutrition, Health, and Disease, Oxford University Press Inc., New York 1996.

5 Halliwell, B.; Encyclopedia of life sciences, 2001, Nature Publishing Group, 1-7.

6 Vroegop, S. M.; Decker, D. E.; Buxser, S. E. Free Radic. Biol. Med. 1995, 18, 141.

7 Breen, A.P.; Murphy, J. A. Free Radic. Biol. Med. 1995, 18, 1033. https://doi.org/10.1016/0891-5849(94)00209-3

8 Pace, G. W.; Leaf, C. D. Free Radic. Biol. Med. 1995, 19, 523. https://doi.org/10.1016/0891-5849(95)00047-2

9 Aruoma, O. I. Free Radic. Biol. Med. 1996, 20, 675. https://doi.org/10.1016/0891-5849(95)02110-8

10 Schwarz, K. B. Free Radic. Biol. Med. 1996, 21, 641. https://doi.org/10.1016/0891-5849(96)00131-1

11 Viglianisi, C.; Menichetti, S.; Morelli, P.; Baschieri, A.; Amorati, A. Heteroatom Chemistry 2018, e21466. https://doi.org/10.1002/hc. 21466 https://doi.org/10.1002/hc. 21466

12 Ingold, K. U. Chem. Rev. 1961, 61, 563. https://doi.org/10.1021/cr60214a002

13 Finkel, T.; Holbrook N. J., Nature, 2000, 408, 239. https://doi.org/10.1038/35041687

14 Lucarini, M.; Pedulli, G. F. Chem. Soc. Rev. 2010, 39, 2106. https://doi.org/10.1039/b901838g 
15 Middleton Jr, E.; Kandaswarni, C. in The Flavonoids Advances in Research Since 1986, (Ed. J. B. Harborne), Chapman \& Hall, London, 1994, pp. 619-645.

16 Bohm, B. A. Introduction to Flavonoids, Harwood Academic Publishers, Amsterdam, 1998 and references cited therein.

17 Dixon, R. A.; Ferreira, D. Phytochemistry 2002, 60, 205.

https://doi.org/10.1016/S0031-9422(02)00116-4

18 Burton, G. W.; Ingold, K. U. Acc. Chem. Res. 1986, 19, 194.

https://doi.org/10.1021/ar00127a001

19 Jiang, Q. Free Rad. Biol. Med. 2014, 72, 76.

https://doi.org/10.1016/i.freeradbiomed.2014.03.035

20 Viglianisi, C.; Amorati, R.; Di Pietro, L.; Menichetti, S. Chem. Eur. J. 2015, 21, 16639.

https://doi.org/10.1002/chem.201502650

21 Menichetti, S.; Amorati, R.; Meoni, V.; Tofani, L.; Caminati, G.; Viglianisi, C. Org. Lett. 2016, $18,5464$. https://doi.org/10.1021/acs.orglett.6b02557

22 Capozzi, G.; Falciani, C.; Menichetti, S.; Nativi, C. J. Org. Chem. 1997, 62, 2611.

https://doi.org/10.1021/jo962014m

23 Capozzi, G.; Lo Nostro, P.; Menichetti, S.; Nativi, C.; Sarri, P. Chem. Commun. 2001, 551. https://doi.org/10.1039/b100359n

24 Menichetti, S.; Aversa, M. C., Cimino, F.; Contini, A.; Viglianisi, C.; Tomaino, A. Org. Biomol. Chem. 2005, 3, 3066.

https://doi.org/10.1039/b507496g

25 Lodovici, M.; Menichetti, S.; Viglianisi, C.; Caldini, S.; Giuliani, E. Bioorg. Med. Chem. Lett. 2006, $16,1957$. https://doi.org/10.1016/j.bmcl.2005.12.078

26 Amorati, R.; Cavalli, A.; Fumo, M. G.; Masetti, M.; Menichetti, S.; Pagliuca, C.; Pedulli, G. F.; Viglianisi, C. Chem. Eur. J. 2007, 13, 8223.

https://doi.org/10.1002/chem.200700309

27 Amorati, R.; Catarzi, F.; Menichetti, S.; Pedulli, G. F.; Viglianisi, C. J. Am. Chem. Soc. 2008, 130, 237. https://doi.org/10.1021/ja075554h

28 Menichetti, S.; Amorati, R.; Bartolozzi, M. G.; Pedulli, G. F.; Salvini, A.; Viglianisi, C. Eur. J. Org. Chem. 2010, 2218.

https://doi.org/10.1002/ejoc.200901493

29 Zahalka, H. A.; Robillard, B.; Hughes, L.; Lusztyk, J.; Burton, G. W.; Janzen, E. G.; Kotake, Y.; Ingold, K. U. J. Org. Chem. 1988, 53, 3739.

https://doi.org/10.1021/jo00251a014

30 Politzer, P.; Murray, J. S.; Clark, T. Phys. Chem. Chem. Phys. 2013, 15, 11178.

https://doi.org/10.1039/c3cp00054k

31 Beno, B. R.; Yeung, K.-S.; Bartberger, M. D.; Pennington, L. D.; Meanwell, N. A. J. Med. Chem. 2015, 58, 4383.

https://doi.org/10.1021/jm501853m

32 Fick, R. J.; Kroner, G. M.; Nepal, B.; Magnani, R.; Horowitz, S.; Houtz, R. L.; Scheiner, S.; Trievel, R. C. ACS Chem. Biol. 2016, 11, 748.

https://doi.org/10.1021/acschembio.5b00852

33 Turbiez, M.; Frere, P.; Allain, M.; Videlot, C.; Ackermann, J.; Roncali, J. Chem. Eur. J. 2005, 11, 3742-3752. https://doi.org/10.1002/chem.200401058 
34 Fanfrlik, J.; Prada, A.; Padelkova, Z.; Pecina, A.; Machacek, J.; Lepsik, M.; Holub, J.; Ruzicka, A.; Hnyk, D.; Hobza, P. Angew. Chem., Int. Ed. 2014, 53, 10139.

https://doi.org/10.1002/anie.201405901

35 Nziko, V. de P. N.; Scheiner, S. J. Org. Chem. 2015, 80, 2356.

https://doi.org/10.1021/acs.joc.5b00012

36 Viglianisi, C.; Marcantoni, E.; Carapacchi, V.; Menichetti, S.; Marsili, L. Eur. J. Org. Chem. 2014, 6405. https://doi.org/10.1002/ejoc.201402894

37 Viglianisi, C.; Vasa, K.; Tanini, D.; Capperucci, A.; Amorati, R.; Valgimigli, L.; Baschieri, A.; Menichetti, S. Chem. Eur. J. 2019, 25, 9108.

38 Anchel, M.; Blatt, A. H. J. Am. Chem. Soc. 1941, 63, 1948.

https://doi.org/10.1021/ja01852a045

39 Loudon, J. D.; Razdan, R. K. J. Chem. Soc. 1954, 4299.

https://doi.org/10.1039/jr9540004299

40 Anastasis, P.; Brown, P. E. J. Chem. Soc. Perkin Trans. 1 1982, 2013.

https://doi.org/10.1039/p19820002013

41 Bellamy, D. Chazan, J. B.; Ou, K. Tetrahedron 1983, 39, 2803.

https://doi.org/10.1016/S0040-4020(01)82450-9

42 Tanaka, T.; Miyaguchi, M.; Mochisuki, R. K.; Tanaka, S.; Okamoto, M.; Kitajima, Y.; Miyazaki, T. Heterocycles 1987, 25, 463.

https://doi.org/10.3987/S-1987-01-0463

43 Levy, J.-N.; Latham, C. M.; Roisin, L.; Kandziora, N.; Di Fruscia, P.; White, A. J. P.; Woodward, S.; Fuchter, M. J. Org. Biomol. Chem. 2012, 10, 512

https://doi.org/10.1039/C10B06780J

44 Killander, D.; Sterner, O. Eur. J. Org. Chem. 2014, 6507.

https://doi.org/10.1002/ejoc.201402722

45 Burton, G. W.; Doba, T.; Gabe, E. J.; Hughes, L.; Lee, F. L.; Prasad, L., Ingold, K. U. J. Am. Chem. Soc. 1985, $107,7053$.

https://doi.org/10.1021/ja00310a049

46 Lucarini, M.; Pedulli, G. F. Chem. Soc. Rev., 2010, 39, 2106.

https://doi.org/10.1039/b901838g

47 Nam, T-g.; Rector, C. L.; Kim, Hye-y.; Sonnen, A. F.-P. Meyer, R.; Nau, W. M.; Atkinson, J.; Rintoul, G.; Pratt, D. A.; Porter, N. A. J. Am. Chem. Soc. 2007, 129, 10211.

https://doi.org/10.1021/ja072371m

48 Amorati, R.; Baschieri, A. Valgimigli, L. J. Chem. 2017, 6369358.

https://doi.org/10.1155/2017/6369358

49 Viglianisi, C.; Bartolozzi, M. G.; Pedulli, G. F.; Amorati, R.; Menichetti, S. Chem. Eur. J. 2011, 17, 12396.

https://doi.org/10.1002/chem.201101146 